\title{
The Right to Have Digital Rights in Smart Cities
}

\author{
Igor Calzada $1,2,3$ (D)
}

check for updates

Citation: Calzada, I. The Right to Have Digital Rights in Smart Cities. Sustainability 2021, 13, 11438. https:/ / doi.org/10.3390/su132011438

Academic Editor: Harald A. Mieg

Received: 10 September 2021

Accepted: 13 October 2021

Published: 16 October 2021

Publisher's Note: MDPI stays neutral with regard to jurisdictional claims in published maps and institutional affiliations.

Copyright: (C) 2021 by the author. Licensee MDPI, Basel, Switzerland. This article is an open access article distributed under the terms and conditions of the Creative Commons Attribution (CC BY) license (https:/ / creativecommons.org/licenses/by/ $4.0 /)$.
1 Civil Society Centre ESRC, School of Social Sciences, Cardiff University, Wales Institute of Social and Economic Research and Data (WISERD), 38 Park Place, Cathays Park, Cardiff-Caerdydd CF10 3BB, UK; calzadai@cardiff.ac.uk; Tel.: +44-(0)-7887661925

2 Urban Transformations ESRC, COMPAS, University of Oxford, 58 Banbury Road, Oxford OX2 6QS, UK

3 People-Centered Smart Cities Flagship Programme, Digital Transformation in Urban Areas, UN-Habitat, P.O. Box 30030, Nairobi GPO 00100, Kenya

\begin{abstract}
New data-driven technologies in global cities have yielded potential but also have intensified techno-political concerns. Consequently, in recent years, several declarations/manifestos have emerged across the world claiming to protect citizens' digital rights. In 2018, Barcelona, Amsterdam, and NYC city councils formed the Cities' Coalition for Digital Rights (CCDR), an international alliance of global People-Centered Smart Cities-currently encompassing 49 cities worldwide-to promote citizens' digital rights on a global scale. People-centered smart cities programme is the strategic flagship programme by UN-Habitat that explicitly advocates the CCDR as an institutionally innovative and strategic city-network to attain policy experimentation and sustainable urban development. Against this backdrop and being inspired by the popular quote by Hannah Arendt on "the right to have rights", this article aims to explore what "digital rights" may currently mean within a sample consisting of 13 CCDR global people-centered smart cities: Barcelona, Amsterdam, NYC, Long Beach, Toronto, Porto, London, Vienna, Milan, Los Angeles, Portland, San Antonio, and Glasgow. Particularly, this article examines the (i) understanding and the (ii) prioritisation of digital rights in 13 cities through a semi-structured questionnaire by gathering 13 CCDR city representatives/strategists' responses. These preliminary findings reveal not only distinct strategies but also common policy patterns.
\end{abstract}

Keywords: digital rights; smart cities; people-centered smart cities; social innovation; institutional innovation; technological innovation; policy experimentation; action research; online research; COVID-19

\section{Introduction: 'The Right to Have Digital Rights'}

COVID-19 has hit citizens dramatically, not only creating a general risk-driven environment encompassing a wide array of economic vulnerabilities but also exposing people to pervasive digital risks, such as biosurveillance, misinformation, and e-democracy algorithmic threats [1-3]. Furthermore, it has inevitably raised the need to resiliently and techno-politically respond to threats that hyper-connected and highly viralised societies produce [4]. Consequently, over the course of the pandemic, a debate has emerged in several global People-Centered Smart Cities [5-9] regarding the appropriate techno-political response when governments use disease surveillance technologies to tackle the spread of COVID-19 [10-15], pointing out the dichotomy between state-Leviathan cybercontrol and civil liberties [16-18].

In many ways, the pandemic, has unprecedentedly brought into sharp relief digital rights issues on which several agents had been working for years in cities worldwide [5,19-21]. Thus, the digital rights' claim could be directly seen as a social innovation that is evolving towards an institutional innovation [22-24]. The digital rights' claim, articulated via city networks, is currently offering new modes of urban governance for policy experimentation in city administrations worldwide $[6-8,25]$. As such, these kinds of digital rights-driven projects based on policy experimentations attempt to subvert the 
ongoing urban politics and governmentality that lack sustainability, with traditional siloed city administrations remaining a central obstacle to sustainable urban development and people-centered smart cities [26]. Digital rights are fundamental rights in the digital age related to privacy protection in smart cities [27-30]. In this vein, it has encouraged the United Nations to take an advocacy role regarding the 'right to have digital rights' and create the Hub for Human Rights and Digital Technology [31] (p. 1): 'Together, as we seek to recover from the pandemic, we must learn to better curtail harmful use of digital technology and better unleash its power as a democratising force and an enabler'.

In 1949, Hannah Arendt [32] wrote a phrase that has gradually become one of her most quoted and often interpreted: 'the right to have rights.' The phrase summed up her scepticism about the concept of human rights-those rights that, in theory, belong to every person by virtue of existence [31-36]. According to Arendt, the only way for these rights to be guaranteed was being not only a person but also a citizen [37]. This quotation may resemble the current post-COVID-19 algorithmic times, when, in the age of digitisation and datafication, dealing responsibly with citizens' rights and data poses a dilemma: on the one hand, there is the tangible added value of processing citizens' personal data by private sector organisations, but on the other hand, there is the claim that individuals should retain control over these data and consequently derived civilian rights [38-42]. Amid surveillance capitalism and beyond a human rights-based approach of Artificial Intelligence (AI) governance [43,44], state-based dataveillance mechanisms like biometrics [45], vaccine passports [46-49], biobanks, and the Internet within the context of citizenship inevitably force us to reclaim 'the right to have digital rights' [49-53].

Calls for the protection of citizens' digital rights have resulted in countless reports, manifestos, organisations, projects, and political declarations in different regional, national, supranational, and global contexts $[5,19,54-57]$. Citizens have traditionally reasserted their positions in relation to the state by claiming human and civil rights and making rights claims. However, the triangle between the state, the market, and the citizenry requires careful balance to protect civic digital rights and liberties and to enable participation and active citizenship [58,59].

The globally widespread phenomenon of the algorithmic disruption has led to new consequences-such as hyper-targeting through data analytics, facial recognition, and individual profiling - received by many as threats and resulting in not-so-desirable outcomes, such as massive manipulation and control via a surveillance capitalism push in the United States (US) [60,61] and the 'Social Credit System' in China [62-64]. In contrast, these techno-political concerns raised a debate in Europe that crystallised into the General Data Protection Regulation (GDPR), which came into force in May 2018. The emergence of the algorithmic disruption has spurred a call to action for cities in the European Union (EU), establishing the need to map out the techno-political debate on 'datafication' or 'dataism' $[1,65,66]$. Moreover, the disruption has also highlighted the potential requirements for establishing regulatory frameworks to protect digital rights from social innovation and institutional innovation. Such policy experimentation frameworks for urban governance cover demands for privacy, ownership [67], trust, access, ethics, AI transparency [68], algorithmic automatisation [69], and, ultimately, democratic accountability [70].

Alongside the algorithmic disruptive phenomena, data technologies alter not only the corpus of citizens' rights but also the way in which cities conceive and deliver public policy and services to protect these rights [71]. This digital transformation pervasively encompasses all angles of policy experimentation in city administrations: the provision of services, the assignment of resources, the approach to solving social problems, and even the complex decision-making process are increasingly shifting to software algorithms and evolving toward considering citizens as merely data-providers rather than decision-makers [67,72]. This transformational process, stemming from a 'black-boxed' algorithmic momentum, is often perceived as a mechanism that increases the efficiency of existing approaches or as simply a process of policy adjustment [73]. However, further policy experimentation 
and advocacy stemming from social innovation and institutional innovation seem to be necessary in light of the current demands from city administrations worldwide (Figure 1).

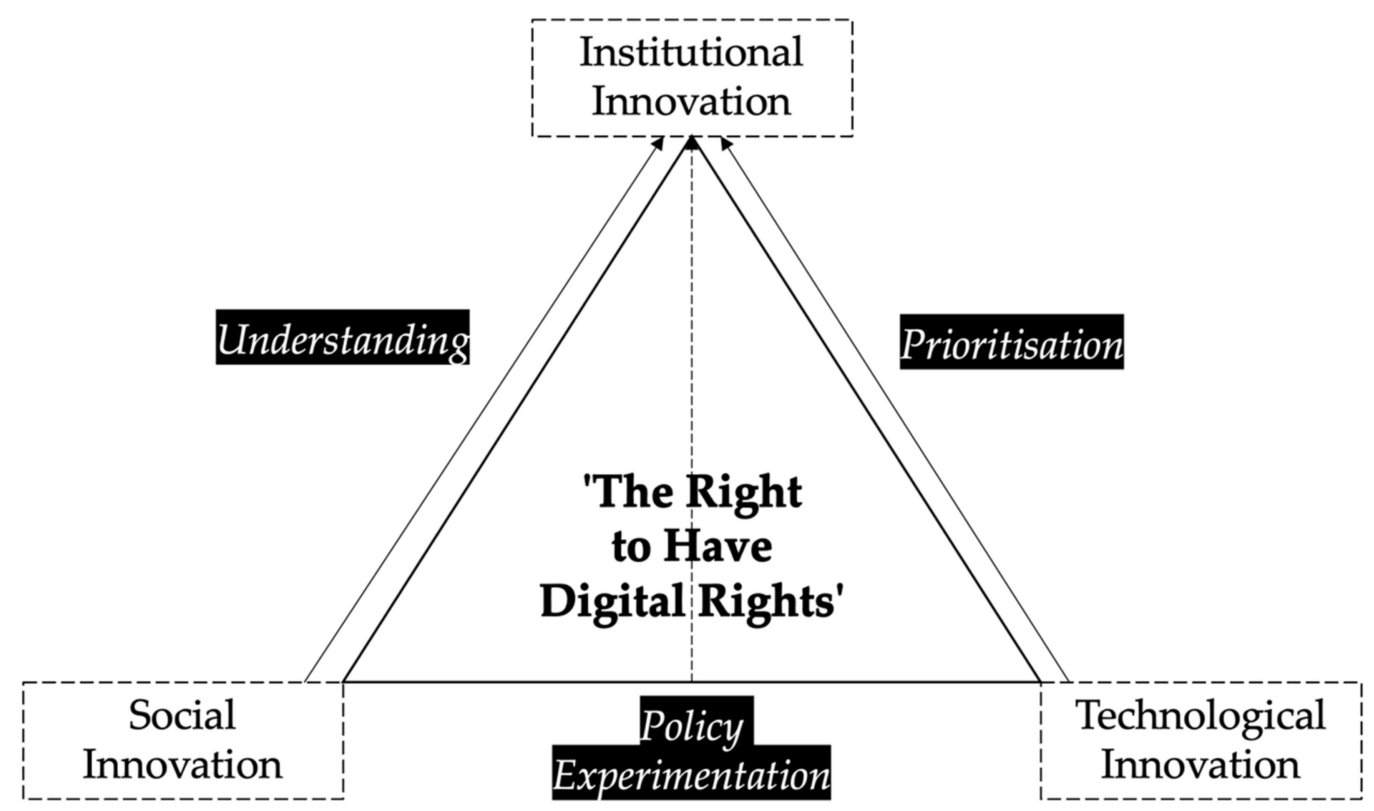

Figure 1. Social, institutional, and technological innovations: Policy experimentations to explore understanding and prioritisation of digital rights.

A direct outcome of this policy advocacy was the Declaration of the Cities' Coalition for Digital Rights [74] manifesto, which was translated into data policy by building networked data infrastructures and institutions alongside policy recommendations for 'people-centered smart cities' [75]. The CCDR, an international alliance of global, peoplecentered smart cities, was formed in 2018 by the Barcelona, Amsterdam, and New York City (NYC) city councils to promote citizens' digital rights on a global scale. This broad movement has gradually expanded under the leadership of Barcelona, Amsterdam, and NYC [76]. Today, the movement comprises an additional 46 cities-including Athens, Balikesir, Berlin, Bordeaux, Bratislava, Cluj-Napoca, Dublin, Glasgow, Grenoble, Helsinki, La Coruña, Leeds, Leipzig, Liverpool, London, Lyon, Milan, Moscow, Munich, Nice, Porto, Rennes Metropole, Roma, Stockholm, Tirana, Turin, Utrecht, Vienna, and Zaragoza in Europe; Amman in the Middle East; and Atlanta, Austin, Cary, Chicago, Guadalajara, Kansas City, Long Beach, Los Angeles, Montreal, Philadelphia, Portland, San Antonio, San José, Sao Paulo, and Toronto in the Americas; and Sydney in Australia.

Hence, this article aims to explore what 'the right to have digital rights' may currently mean in a sample consisting of 13 CCDR global people-centered smart cities' strategic formulation (Barcelona, Amsterdam, NYC, Long Beach, Toronto, Porto, London, Vienna, Milan, LA, Portland, San Antonio, and Glasgow) by analysing (i) the understanding of digital rights and (ii) the degree of priority of the several digital rights.

Consequently, the research question of this article is: How are 13 CCDR global peoplecentered smart cities implementing their city strategies advocating digital rights? The article focused on two digital rights-related factors: (i) the understanding and (ii) the prioritisation of digital rights. In response to this research question, this article provides preliminary findings and an overview through an exploratory and progressive action research process carried out via online fieldwork research by collecting specifically responses and strategic formulations around digital rights from 13 CCDR city representatives/strategists on 18 November 2020. Data collection was articulated through a semi-structured questionnaire consisting of 11 questions (7 closed-ended questions and 4 open-ended questions; Appendix A) resulting in a comparative, exploratory, and in-depth examination of the two digital rights-related factors. Specifically, the 13 responses and strategic formulations from 
the city representatives/strategists were collected directly during the General Assembly of the CCDR on 18 November 2020 at the Smart City Expo World Congress 2020 (SCEWC2020) in a session accurately tailored for data collection that was called the 'Survey Filling Party'. The way in which this exploratory and progressive action research was conducted through an iterative and cyclic design, will be broadly explained in the Section 3 of this article entitled 'Methods: Progressive and Exploratory Action Research Process'.

The article is structured as follows: (i) in the Section 2, a literature review about digital rights is presented; (ii) in the Section 3 , the methods through an exploratory and progressive action research via online fieldwork research are presented including their rationale, research design, and sample; (iii) in the Section 4, results and preliminary findings of this action research around CCDR will be presented and discussed; and finally (iv), the article concludes with several final remarks and future research avenues in relation to digital rights as new modes of urban governance for city administrations.

\section{Literature Review: Digital Rights}

Over the last decade, the increasing propagation of sensors and data collection machines in so-called 'smart cities' by both the public and the private sector has created democratic challenges around AI, surveillance capitalism, and protecting citizens' digital rights to privacy and ownership [4,72,77-79]. The demise of democracy is clearly already one of the largest policy challenges in the post-COVID-19 hyperconnected and highly viralised societies for global 'people-centered smart cities' [80]. There is no question that the political and regulatory choices related to digital technologies in the so-called smart cities raise a variety of human rights concerns, ranging from freedom of expression to access, privacy, and other political and ethical questions. Invasions of privacy, increasing dataveillance, and digital-by-default commercial and civic transactions are clearly eroding the democratic sphere by undermining citizens' perception of their digital rights [81].

Against this backdrop, the concept of the smart city, having been highly contested from a critical academic standpoint stemming from social innovation [82-84] was recently reframed and coined by the UN-Habitat program as 'people-centered smart cities' $[4,6,8]$. The new categorisation creates not only an urban paradigm for the Global North but also for the Global South by decolonising the urban standpoint [85-87]. The use of the term 'people-centered smart cities' supports UN-Habitat's endeavour to back (among other city networks) the CCDR global cities, thus shaping a digital future that puts people first and helps bridge the social, digital, and data divide [7,47]. UN-Habitat's 'people-centered smart cities' definition-clearly resonating with social innovation-highlights the fact that smart cities should serve the people and improve living conditions for all. Far from being bypassed, the key aspect of this definition is the acknowledgement that national governments are overwhelmed by the complexity of digital policies, while municipalities rarely have the in-house skills to create 'people-centered smart city' projects or to execute holistic impact assessments on the agreements they sign with private companies. For UN-Habitat, digital rights are intrinsically in the core of 'people-centered smart cities' insofar as cities are in a privileged position to strategise institutional innovation and deploy digital rights-related aspects among their fellow citizens.

Recently, a range of literature about digital rights has appeared in different disciplinary perspectives $[37,39,41,44,51,59,81,88]$ alongside a large corpus encompassing high-profile reports, institutional declarations in different supranational [56], national, regional, and global contexts as well as empirical datasets such as atlases [89] and rankings [90]. On the one hand, for several authors, algorithmic disruption has raised the question of how citizenship can be redefined through the incorporation of new digital rights related to the status of a citizen in cyberspace-access, openness, net-neutrality, digital privacy, data encryption, protection and control, digital/data/technological sovereignty $[75,85,91]$. On the other hand, the authors of recent declarations include not only civil society organizations but also various coalitions of states, international organisations, industry actors-framing 
digital rights in terms of corporate social responsibility-as well as city coalitions such as the one examined in this article: The Cities' Coalition for Digital Rights (CCDR).

Digital rights have been rather present in academic debates over the last years particularly under the banner of 'Digital Rights Management' understood as a systematic approach to copyright protection for digital media [92]. This approach focuses on a set of access control technologies for restricting the use of proprietary hardware and copyrighted works. More recently, though, the digital rights have been understood in a complementary fashion as follows: Pangrazio and Sefton-Green argued that 'digital rights are human and legal rights that allow citizens to access, use, create, and publish digital content on devices such as computers and mobile phones, as well as in virtual spaces and communities' [81] (p. 19). Currently, digital rights are not only a set of rights in and of themselves but are also related to other human rights, particularly freedom of expression and the right to privacy in online and digital environments [93]. In practical terms, human rights can be thought of as protection against standard threats—-such as oppression, deprivation, and violence- that jeopardize human interests very much related to the notion of alienation and data justice $[44,85,93]$.

Complementing the previous approaches, according to Daskal [94] (p. 241), 'civil society organisations have been advocating digital rights aiming to construct the socialpolitical-cultural identity of a generation who are knowledgeable, politically active, and aware of their rights in the digital age.' Daskal concluded that civil society organisations attempt through advocation of digital rights to (i) deliver accurate technological and political information, (ii) propel citizens towards participation, and (iii) sell merchandise to citizens.

Timelier though, is Kitchin's [18] suggestion that in the early response to COVID-19, there was no sufficient consideration of the consequences for civil liberties, biopolitics, or surveillance capitalism, whether the supposed benefits outweighed any commensurate negative side effects, or whether public health ambitions could be realised while protecting civil liberties.

Inevitably, in the aftermath of COVID-19, and even in a resilient quick reaction to an emergency, the response given by CCDR people-centered smart cities shows how relevant it has become for policymakers to elucidate how data are collected, by whom, for what purpose, and how they are accessed, shared, and re-used [95]. CCDR cities including Amsterdam (implementing 'Unlock Amsterdam' to check on which tech could be used to ease the lockdown process), Barcelona (opting for the extension of Telecare for elderly people living alone), Helsinki (emphasising the need to have the right data on health, social life, and the economy), NYC (distributing tablets to vulnerable and disconnected communities), and San Antonio (developing an open data hub for citizens and interested stakeholders to access updated statistical information on COVID-19 on a daily basis) are just a few examples to show the importance of claiming digital rights in pandemic times.

Digital rights capture the techno-political tension among 'subjects of rights, objectives, constraints, and governance framework' [41] (p. 312). Thus, beyond their status as existing legal obligations, digital rights can be articulated through a variety of political issues and employed by different actors for different purposes. As such, from a critical standpoint, remarkably, Karppinen and Puukko [41] criticise those current debates for failing to acknowledge that rights are not simply rules and defences against power: rights claims might often emerge from civil society, but they can also be used as vehicles of power, and structures of governance. Furthermore, these authors consider that concept of digital rights itself 'remains vague and malleable' [41] (p. 309). Nonetheless, in line with the examination of the CCDR city cases in this article from the social and institutional innovation perspective, they also argue that 'actors that take part in these initiatives and processes all contribute to a discursive exchange where the principles are crystallised and perhaps eventually institutionalised' [41] (p. 324), as is clearly the case with the CCDR.

Probably the more comprehensive contribution to the contextualisation of digital rights was made by Isin and Ruppert [88]. For them, five digital rights have emerged in cyberspace 
so far: (i) expression, (ii) access, (iii) privacy, (iv) openness, and (v) innovation. Their position stems from Arendt's [32] understanding of rights in legal and not performative terms, which essentially means that there can be no human digital rights without citizenship rights: either human digital rights are the rights of those who have no digital rights or the rights of those who already have digital rights, being citizens. Thus, Isin and Ruppert [88] define a comprehensive list and definitions of five digital rights: (i) expression as blocking censorship of Internet; (ii) access as promoting universal access to fast and affordable networks; (iii) openness as keeping the Internet an open network where everyone is free to connect, communicate, write, read, watch, speak, listen, learn, create, and innovate; (iv) innovation as protecting the freedom to innovate and create without permission; and (v) privacy as protecting privacy and defending people's ability to control how their data and devices are used.

Insofar as this literature review is eminently focused on digital rights rather than smart cities, several key references on smart cities have been explicitly cited so far [28-30], Table 1 depicts several taxonomies about digital rights: first, the taxonomy by Isin and Ruppert [88]. Second, the taxonomy on the Charter of Human Rights and Principles for the Internet [86] shows a comprehensive list of 19 digital rights. Third, the taxonomy of the book Smart City Citizenship by the author of this article encompasses 14 digital rights [4]. These references by the author, like others that are illustrated $[65,67,75,82,85,96]$, are essential to situate this article, insofar as it stems from these references. Eminently, these references build the argument of this article, and these previous works contribute to providing the necessary literature review about smart cities. Furthermore, this literature review on digital rights and its connection with smart cities should not be taken for granted in the literature about the latter. Accordingly, the fact that smart cities have been eminently portrayed as an essential technocratic term should not be bypassed. This aspect is broadly a novel turning point [4] and an approach worth pointing out in this article in light of the new smart city reframing by UN-Habitat called 'people-centered smart cities' [6,8]. Fourth, and ultimately, the operational taxonomy formulated by the CCDR [76], which encompasses five digital rights, will be the only one used from now onwards to directly serve the purpose of this article.

Table 1. Digital rights' taxonomies.

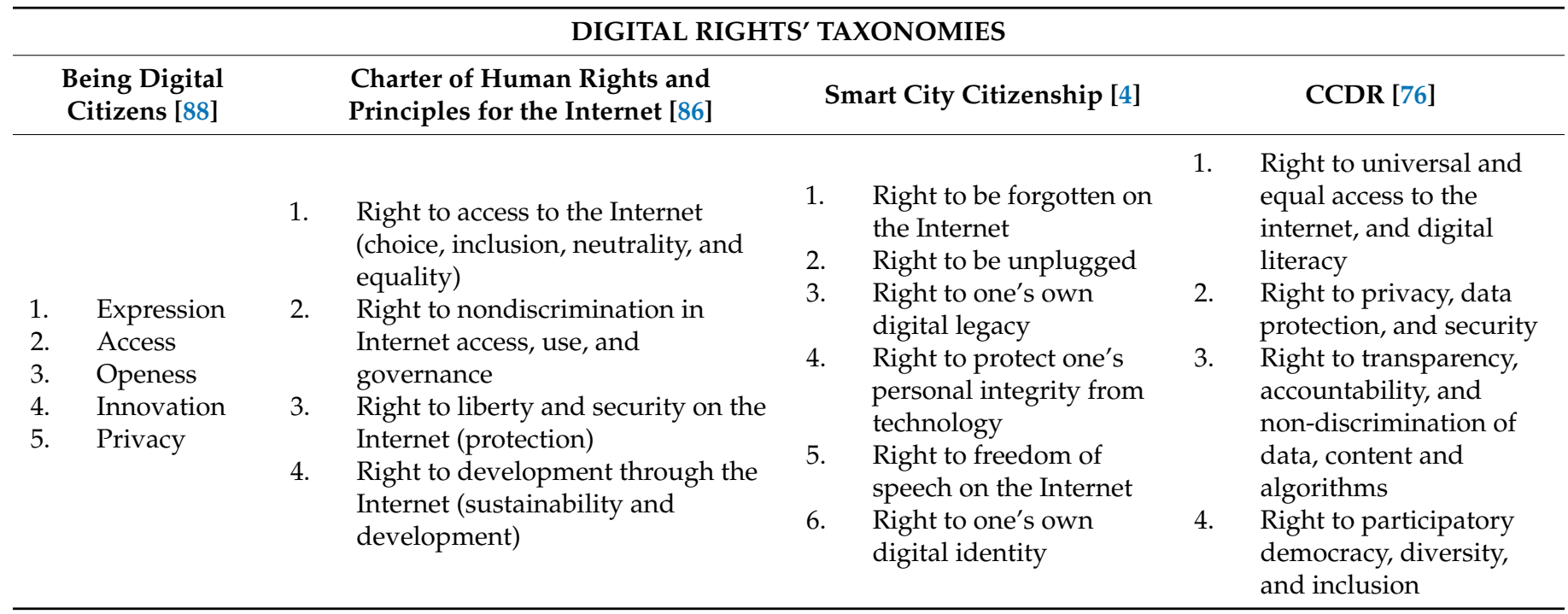


Table 1. Cont.

\begin{tabular}{|c|c|c|c|c|c|}
\hline \multicolumn{6}{|c|}{ DIGITAL RIGHTS' TAXONOMIES } \\
\hline $\begin{array}{l}\text { Being Digital } \\
\text { Citizens [88] }\end{array}$ & & $\begin{array}{l}\text { Charter of Human Rights and } \\
\text { Principles for the Internet [86] }\end{array}$ & Smart City Citizenship [4] & & CCDR [76] \\
\hline $\begin{array}{l}\text { Expression } \\
\text { Access } \\
\text { Openess } \\
\text { Innovation } \\
\text { Privacy }\end{array}$ & $\begin{array}{l}11 . \\
12 . \\
13 .\end{array}$ & $\begin{array}{l}\text { Freedom of expression and } \\
\text { information on the Internet } \\
\text { (freedom to protest, right to } \\
\text { information, freedom from } \\
\text { censorship, and freedom from hate } \\
\text { speech) } \\
\text { Freedom of religión and belief on } \\
\text { the Internet } \\
\text { Freedom of online assembly and } \\
\text { association } \\
\text { Right to privacy on the Internet } \\
\text { (anonymity, freedom from } \\
\text { surveillance, and freedom from } \\
\text { defamation) } \\
\text { Right to digital data protection } \\
\text { (protection of personal data, use of } \\
\text { personal data, and obligations of } \\
\text { data collectors) } \\
\text { Right to education on and about the } \\
\text { Internet } \\
\text { Right to culture and access to } \\
\text { knowledge on the Internet } \\
\text { Rights of children and the Internet } \\
\text { Rights of people with disabilities } \\
\text { and the Internet } \\
\text { Right to work and the Internet } \\
\text { Right to online participation in } \\
\text { public affairs } \\
\text { Rights to consumer protection on } \\
\text { the Internet } \\
\text { Right to health and social services } \\
\text { on the Internet } \\
\text { Right to legal remedy and fair trial } \\
\text { for actions involving the Internet } \\
\text { Right to appropriate social and } \\
\text { internatioanl order for the Internet } \\
\text { (governance, multilingualism, and } \\
\text { pluralism) }\end{array}$ & 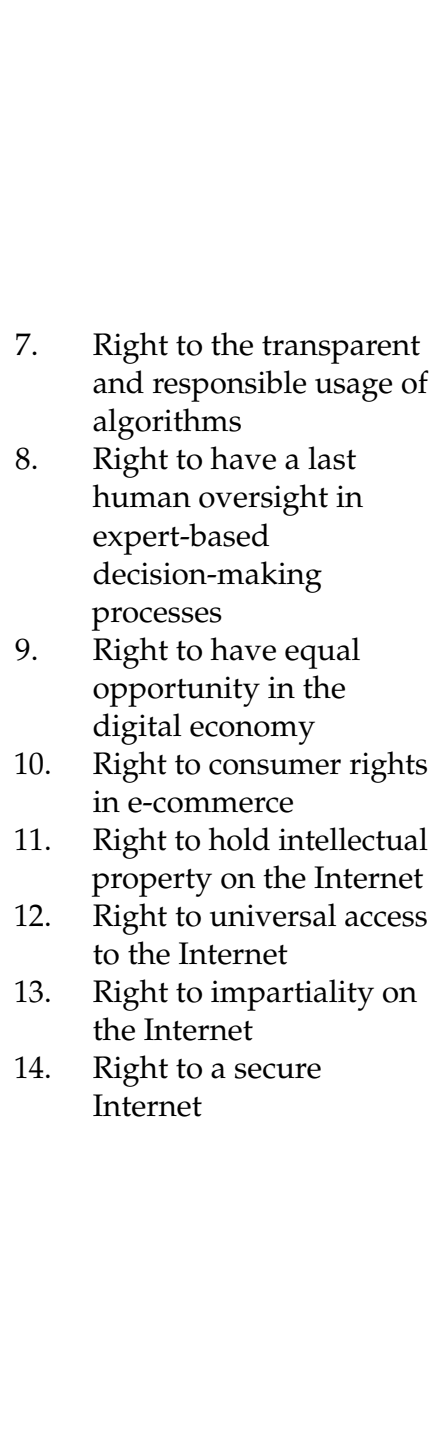 & 5. & $\begin{array}{l}\text { Right to open and } \\
\text { ethical digital service } \\
\text { standards }\end{array}$ \\
\hline
\end{tabular}

\section{Methods: Exploratory and Progressive Action Research Process}

This section shows the methodological process employed by this research following action research guidelines stemming from social innovation [97]. First and foremost, it is worth defining 'action research' as an umbrella term which covers a variety of approaches to 'action-oriented' research. Action research involves researchers and participants working together to examine a problematic situation, take action to change it for the better, or simply analyse the implications of a strategic formulation. The latter option applies to this article. Based on the same idea, Reason and Bradbury define action research as 'a democratic process concerned with developing practical knowing in the pursuit of worthwhile human purposes which involves action and reflection, theory, and practice, in participation with others' [98] (p. 1). This action research process was built in collaboration with the CCDR core team from the very beginning of it, in May 2020, involving practitioners and academics.

The first wave of action research was developed in the 1940s; Kurt Lewin coined the term. The second wave followed in the 1960s and 1970s when Brazilian educator Paulo Freire developed community-based research processes. It was in the 1980s that 
action research gained traction in community development and international development contexts. In the 1990s, action research gained popularity within minority world institutions and was blended with critical social sciences.

Action research combines both (i) action-the research encompasses activity and generates changes-and research-which actively engages people in the whole research process and cycle. Participants in action research are not subjects, informants, and researched people. Participation in action research varies from project to project and, at certain points of the research, by permanently questioning who participates, when, and why. Action researchers and participants can use qualitative and quantitative techniques. This point is clarifying in the context of this article insofar as the semi-structured questionnaire presents 11 questions - 4 of which are opened-ended questions without any indications (Q1, Q4, Q5, and Q10), while the remaining 7 closed-ended questions offer specific options to select as answers. In light of the designed action research method of this article, this clarification is rather remarkable insofar as this exploratory and progressive action research process responded through qualitative and quantitative modes to the research question. This article seeks to answer the following research question: How are 13 CCDR global peoplecentered smart cities implementing their city strategies advocating digital rights? Thus, this article aims to explore, rather than simply compare, cities, and the broad and insightful phenomena of the right to have digital rights in smart cities.

Consequently, the rationale, sample, and research design through action research aimed to explore how these 13 cities were dealing with this phenomenon. The author of this article would therefore like to clarify that action research, to some extent, blurs the separation between the qualitative and the quantitative. This article assesses the strategies formulated by their key actors: the city representatives/strategists that encompass the core team of the CCDR. By no means is this article committed to presenting any survey representing the opinion of citizens or communities in the examined cities. Thus, action research as a methodology makes total sense for this purpose. The research design was followed by insights and knowledge generated through interactions between researchers and participants. However, few projects fully involve participants throughout the entire research process. Rather than theory generation, the aim of this action research was to explore how strategy was formulated by hearing directly from the main characters: city representatives/strategists.

This article argues that a less positivist approach should be followed when judging the validity of action research where social innovation processes are involved. Consequently, as the data collection step shows (the 6th methodological step of the research design), the degree of influence of city representatives/strategists in their smart city strategies is considerably high — a fact that cannot be overlooked or ruled out from the more quantitatively pure perspective. A methodological lesson of the process this article covers is that strategies of smart cities should be understood and contextualised comparatively with other cities. As the 6th methodological step of the research design shows, the 'Survey Filling Party' event that was organised for 18 November 2020, city representatives learn from each other and their responses were given in relation to how other cities were constructing their own smart city strategies. The entire process took 12 months (May 2020-2021).

In this article, social, institutional, and technological innovation are analysed through the specific lenses of digital rights. In doing so, action research challenges positivism, which focuses on knowable truths, prediction, quantification, control, and elimination of biases [99]. Actually, action research can even challenge the idea that the researcher is the expert and raise questions about how cities generated their own digital rights and smart city strategy. Another critical aspect in action research processes is the fact that research operational questions (i.e., questions of the semi-structured questionnaire in this article) can be changed and are designed or co-produced by both researchers and participants. The author of this article and the CCDR core team members were researchers, and in parallel, the CCDR core team members and the 13 city representatives/strategists were actually practitioners [99]. 
Action research is a cyclical, flexible, and iterative process that in this article adopts a progressive and exploratory form to better adapt to the research question. As Section 3.2 shows, this cyclical approach was undertaken through eight methodological steps from May 2020 to May 2021. It is also worth clarifying the following methodological observation: because of the uncertainty around the evolution of the pandemic, in May 2020, the research design adopted the form of online research. Since then, an entire research design following action research principles was evolved towards a new online format [100]. It goes without saying that online action research is an unexplored methodology at present, despite the fact that the proliferation of tools and software is remarkable [101]. Nevertheless, and being directly related to the topic of this article, we cannot overlook the ethical and privacy-related aspects that online action research may entail by using such a format. Not surprisingly, though, the more researchers employ the 'Zoom' platform, the more concerns that surface around privacy and ownership issues $[102,103]$. Stemming from this article and the action research methodology used, future research avenues may expand these methodological implications around online research or internet research [104].

Action research in socially distanced postpandemic times requires new exploratory principles, social innovations, and ethics. Furthermore, at present, action research as a method is clearly being affected by the implications of conducting qualitative research remotely and at a distance by collecting data in real-time through online modes. There is a potential for creative new approaches in order to engage with communities, policymakers, stakeholders, and participants in the context of the COVID-19 global pandemic [105]. The eight methodological steps of the action research cycle and process that will be presented under Section 3.2 were adapted to these new online synchronous forums to facilitate the participant response to the semi-structured questionnaire. It is worth considering, however, that this new modality of the online action research process tends to grapple with the following issues: (i) selection of the platform; (ii) ethics and informed consent; (iii) respondents/interviewees; (iv) and online communication including the absence of social clues; (v) data protection; (vi) trust; and (vii) privacy.

To some extent, online action research shows several advantages, as has been the case with the methodology used for this article [100-104]: (i) the improved internet access and increased use of electronic devices globally, such as with online semi-structured questionnaires; (ii) convenience and cost-effectiveness of online methods compared to inperson interviews or focus-groups, particularly when conducting research with participants over a large geographical spread; (iii) online methods that can replicate, complement, and possibly improve upon traditional methods; and (iv) for participants-as was the case during the session on 18 November 2021, called the 'Survey Filling Party'—online methods may be more attractive than in-person interviews due to convenience, efficiency, costeffectiveness, and flexibility.

Disadvantages also exist: (i) some participants may not have access to technology, the internet, or the required skills to use the software selected; (ii) due to technical issues, online may not necessarily mean less time-consuming; (iii) there are issues with connections and time-lags in communication; (iv) the remote and detached nature of face-to-face communication online can worsen the research process; and (v) finally, there are still many open questions regarding which technologies and software should be used to collect data, given the stringent data privacy issue with participants.

As a conclusion of this methodological introduction regarding the use of online action research in the current postpandemic context, this article argues that it is not as straightforward as just transferring the same face-to-face method to an online technology and setting up for action research. In light of the methodological process conducted to carry out online action research, we must ask how this data collection process would have been different if conducted face to face. Given that the data collection process was organised as a specific slot amid the SCEWC2020 online event, we did not identify any hindrances, misalignment, or apparent bias. As Section 3.2 will present, the online action research design consisted of eight methodological steps that allowed for an iterative, 
cyclical, progressive, and exploratory process to respond to the research question of this article [106].

\subsection{Rationale}

In 2018, the CCDR, an international alliance of global people-centered smart cities which currently encompasses 49 cities worldwide, was formed by the Barcelona, Amsterdam, and NYC city councils through a declaration to promote citizens' digital rights on a global scale.

The CCDR creates policies, tools, and resources, in keeping with the Declaration of Human Rights and the principles of the Internet, established within the framework of the UN Internet Governance Forum and in coordination with the United Nations Human Settlements Programme (UN-Habitat), the Office of the High Commissioner for Human Rights (UN Human Rights), United Cities and Local Governments (UCLG) and EUROCITIES.

The CCDR formulated its "Strategy 2020: Action Plan and Roadmap" in 2019 based on five strategies [76]: (i) to build the coalition and promote the five digital rights of the declaration; (ii) to share best practices and know-how, to learn from each other's challenges and successes; (iii) to coordinate common initiatives, actions, and joint events among member cities; (iv) to advocate for relevant international policy processes; and (v) to build communities of digital policy makers to help cities lead by example on digital rights.

Against the backdrop of COVID-19, with the increased use of technologies for contacttracing, video conferencing, geographic mapping, and surveillance, the CCDR recently attempted to go even further in safeguarding digital rights and released a statement regarding the responsible use of technology with regard to pandemic response. While technologies could be leveraged during the pandemic crisis, the CCDR assisted governments and organisations in using them responsibly through 10 principles tied to the CCDR's core values: (i) nexus and proportionality (neither the technologies nor the data collected may be used for purposes other than those deemed strictly necessary for crisis response); (ii) impermanence (once the risk of the pandemic has decreased to insignificant levels, these technologies must no longer be used and all personal data should be deleted); (iii) consent and trust (these technologies cannot be imposed under any of coercion or reward system); (iv) privacy by design (privacy should be evaluated in the context of the real risks of reidentification or other privacy loss, especially when using highly sensitive information such as healthcare data); (v) control (where applicable, technologies should empower citizens to be stewards of their own data); (vi) openness and transparency (technologies must be developed using open technologies, data models, formats, and code, so that the code can be audited, verified and adopted by other cities and organizations, fostering transparency); (vii) responsiveness (technologies for COVID-19 should not be stand-alone measures but should draw upon the existing expertise, needs, and requirements of public health authorities and society, culture, and behaviour, if they are to be effective in combatting the pandemic); (viii) participation (the development of such technologies should consider the needs of all people and include strong feedback loops between policymakers and citizens, with opportunities for iteration); (ix) social innovation (the successful and equitable use of these technologies requires a focus on social innovation, rather than on technological innovation, when they are to be used in everyday life in our societies; and (x) fairness and inclusion (technologies must be accessible and serve all communities, assuring equal accessibility and equal treatment across communities).

Since the start of the pandemic in early 2020, the CCDR tracked and reported observations and lessons learned as various cities confronted the pandemic. Amid these initiatives, the author conducted exploratory action research by collecting data through a semi-structured questionnaire. The data collection process was conducted by gathering responses to the questionnaire from the city representatives of 13 CCDR cases during November 2020, particularly amid the General Assembly that took place on 18 November 2020, held within the policy framework of the Smart City Expo World Congress 2020 
(SCEWC2020), which was employed to complete the sample. Consequently, the sample consisted of the responses provided by the 13 city representatives/strategists who were in charge of formulating the digital rights strategies in their respective cities by 18 November 2020 , as the data collection day.

3.2. Research Design: Eight Methodological Steps for an Online Action Research Iterative, Cyclic, Progressive, and Exploratory Process for an Enquiry on Two Digital Rights-Related Factors

From the very beginning, the research design was elaborated in close collaboration with the CCDR core team by following action research methodological guidelines [106]. This research design thus adopted an online action research format consisting of eight methodological steps. The online action research process was designed between the author of this article and the CCDR core team as an iterative, cyclic, progressive, and exploratory process. The aim of this process was to respond to the research question of this article by looking into how 13 CCDR cities were developing and deploying their digital rights strategies around the five digital rights defined by CCDR [76]. The eight methodological steps are depicted in Figure 2:

\begin{tabular}{|c|c|c|}
\hline $\begin{array}{c}\text { Step 8: } \\
\text { Findings Validation }\end{array}$ & $\begin{array}{c}\text { Step 1: } \\
\text { Desk Research }\end{array}$ & \multirow{3}{*}{$\begin{array}{l}\text { Step 2: } \\
\text { Outlined Version } \\
\text { Semi-Structured } \\
\text { Questionnaire }\end{array}$} \\
\hline With CCDR Core Team & \multirow{2}{*}{$\begin{array}{c}\text { Policy Documents } \\
\text { CCDR Strategy } 2020 \\
{[20,74,76]}\end{array}$} & \\
\hline March-May 2021 & & \\
\hline & May-Aug. 2020 & $\begin{array}{c}\text { Feedback } \\
\text { CCDR Core Team }\end{array}$ \\
\hline $\begin{array}{c}\text { Step 7: } \\
\text { Data Analysis }\end{array}$ & \multirow{3}{*}{$\begin{array}{c}\text { Eight Methodological Steps } \\
\text { for An Online Action Research } \\
\text { Iterative, Cyclic, Progressive, and Exploratory Process } \\
\text { to Inquiry on Two Digital Rights-Related Factors }\end{array}$} & Sept. 2020 \\
\hline With CCDR Core Team & & Step 3 : \\
\hline Dec. 2020-Feb. 2021 & & Research Design: \\
\hline \multirow{4}{*}{$\begin{array}{c}\text { Step 6: } \\
\text { 'Survey Filling } \\
\text { Party' } \\
\text { CCDR General } \\
\text { Assembly } \\
\text { 18 } \\
\text { Dath Nov. } 2020 \\
\text { Data Collection }\end{array}$} & \multirow{3}{*}{$\begin{array}{l}\text { Exploration / Comparative: STRATEGY } \\
13 \text { CCDR People Centered Smart Cities' City } \\
\text { Representatives/Strategists' Responses }\end{array}$} & CCDR Core Team \\
\hline & & $\begin{array}{c}\text { Feedback } \\
\text { CCDR Core Team }\end{array}$ \\
\hline & & Sept. 2020 \\
\hline & \multirow[t]{2}{*}{$\begin{array}{c}\text { Step 5: } \\
\text { Online } \\
\text { Project } \\
\text { Administration }\end{array}$} & \multirow{2}{*}{$\begin{array}{l}\text { Step 4: } \\
\text { Final Version } \\
\text { Semi-Structured } \\
\text { Questionnaire }\end{array}$} \\
\hline & & \\
\hline $\begin{array}{c}\text { SCEWC2020 } \\
\text { htps//inscripcions. } \\
\text { ajuntament.barcelona.cat/index.php/876161 }\end{array}$ & 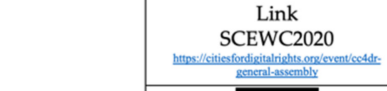 & $\begin{array}{l}7 \text { Closed-Ended Questions } \\
4 \text { Opened-Ended Questions }\end{array}$ \\
\hline Nov. 2020 & Oct. 2020 & Sept. 2020 \\
\hline
\end{tabular}

Figure 2. Eight methodological steps for an online action research iterative, cyclic, progressive, and exploratory process for an enquiry on two digital rights-related factors.

This research design based on the eight methodological steps allowed the author of this article respond to the research question insofar as the process specifically focused on the findings around two digital rights-related factors: (i) the understanding of and (ii) priority of digital rights. Below are explanations for how the semi-structured questionnaire was developed and how it was actually undertaken:

(i) In the first methodological step, desk research was conducted from May to August 2020 to analyse policy documents jointly developed by city-members of the CCDR. This policy analysis was undertaken among the CCDR core team and the author of this article.

(ii) As a result of the first methodological step, in September 2020, the second step took place: an outlined version of a semi-structured questionnaire was designed in its permanent iteration and received feedback from the core team of the CCDR.

(iii) The third step took place in September 2020, when, in collaboration with the CCDR core team, the research design was decided. Despite the fact that the beginning the format was a face-to-face interaction with each city representative/strategist of the 13 CCDR cities, the aftermath of the pandemic prevented the research design from adopting an offline format. 
(iv) The fourth step was achieving the final version of the semi-structured questionnaire. Given the importance of action research principles, the questionnaire included both closed-ended and opened-ended questions. The semi-structured questionnaire was developed through this formal process. It goes without saying that previous publications from the author of this article very much contributed to elaborating some key questions of the questionnaire. In addition, the questionnaire was refined with several trial activities within Barcelona City Council. The involvement of Barcelona City Council during this process was remarkably important.

(v) The fifth step referred to the online project administration. Here, the key collaboration offered by the CCDR core team should be acknowledged. The action research process was managed entirely as an online project administration, both handing over the questionnaire to the 13 city representatives/strategists and arranging an ad hoc event for data collection. That was the next step.

(vi) The sixth step was the data collection through the event organised for 18 November 2020, entitled the 'Survey Filling Party'. This event was included as a core activity in the agenda of the CCDR General Assembly held inside the Smart City Expo World Congress 2020 (SCEWC2020). The process was straightforward, and data collection occurred without any hindrances. Given that it was a separate session inside the whole programme of SCEWC2020, the responses were recorded online in real time, which was essentially a very efficient manner for data collection. In addition, before respondents started responding to the semi-structured questionnaire, the author of this article provided some context around smart cities and digital rights but without influencing how different city representatives/strategists could have answered. Each city representative/strategist received the link to self-complete the questionnaire. The author of this article chaired the whole session by controlling the time allocated to responding and filling in the semi-structured questionnaire online. An important methodological detail was that the respondents had the opportunity to converse among themselves about the opened-ended questions (Q1, Q4, Q5, and Q10), which in itself provided insightful data. The closed-ended responses were not influenced insofar as they involved total self-completion. However, the opened-ended questions sparked interesting discussion that could be seen through the responses received. It should be specified that, from the very beginning of its foundation, the CCDR as a city-network has regularly brought city representatives/strategists together. Thus, they all could follow up on the projects, initiatives, and activities around digital rights that city-members implemented. The semi-questionnaire, by contrast, aimed to explore and focus on the strategic standpoint, probably an aspect that comparatively may have not received enough attention amid the CCDR. The session was efficient, positive, and fruitful.

(vii) Consequently, the seventh step addressed data analysis. This step, again, was undertaken in collaboration with the CCDR core team from December 2020 to February 2021.

(viii) Ultimately, the eighth step validated the findings received through the semi-structured questionnaire. The CCDR core team focuses on the two digital rights-related factors that this article explores: (i) the understanding of and (ii) the priority of digital rights.

\subsection{Sample: 13 CCDR Cities' Representatives/Strategists' Responses/Criteria}

Rather than analysing the different actions performed up to now by the coalition, the methodological rationale behind this article is to explore what 'the right to have digital rights' may currently mean for 13 CCDR city representatives/strategists. The semistructured questionnaire (Appendix A) - as part of an iterative, cyclic, progressive and exploratory online action research process-was designed to operationalise the response to the research question: How are 13 CCDR global people-centered smart cities implementing their city strategies advocating digital rights? The semi-structured questionnaire was therefore the 6th step of this process. Furthermore, how CCDR global people-centered smart cities are articulating their strategies to advocate the right to have digital rights and 
policies to protect citizens was also studied. In the end, this research will contribute to our understanding of how the coalition is impacting city governments in their exercise of advocating for citizens' digital rights.

To respond to the research question formulated in this article, an exploratory action research via online fieldwork research by collecting data from a sample of 13 CCDR cities' representatives/strategists was designed. The research design entirely focused on the operational approach considering five digital rights as the official standpoint of the CCDR (Table 1). The operational taxonomy formulated by the CCDR encompasses five digital rights [76]: (i) right to universal and equal access to the internet, and digital literacy, (ii) right to privacy, data protection, and security, (iii) right to transparency, accountability, and nondiscrimination of data, content, and algorithms, (iv) right to participatory democracy, diversity, and inclusion, and (v) right to open and ethical digital service standards.

The selection of the sample encompassing 13 CCDR cities is justified by the fact that these 13 CCDR cities actively governed the General Assembly 2020, during which the data collection was conducted in November. The semi-structured questionnaire (Appendix A) was filled in by 13 city representatives/strategists appointed for this role by each CCDR city. Regarding response rate, consequently, all the CCDR cities attending the General Assembly filled in the semi-structured questionnaire. Thus, we could consider these 13 cities as the leading and avant-garde group of cities among the rest of the members as they were pushing strategically ahead of the whole CCDR. Figure 3 and Table 2 depict the location and provide insights, respectively, about the 13 CCDR cities in detail.

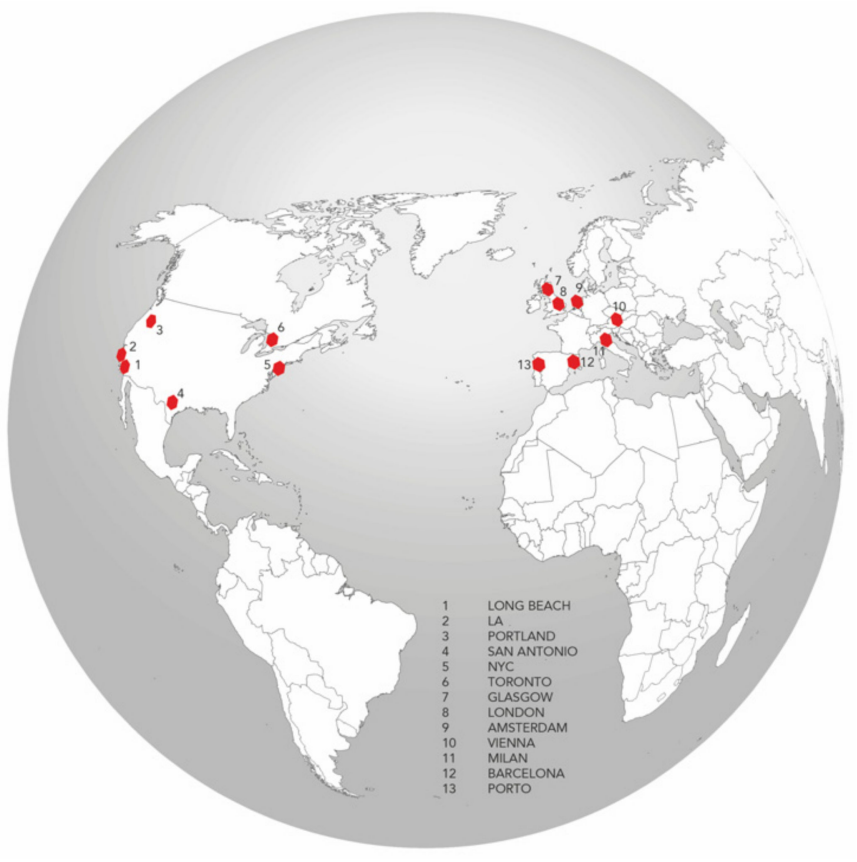

Figure 3. Sample: 13 CCDR smart cities.

Table 2 shows specifically (i) the smart city approach of each city, (ii) the name of the department, and (iii) the list of strategic projects related to digital rights from the social and institutional innovation perspectives [26]. 
Table 2. Description of the sample of the 13 CCDR smart cities (links accessed on 11 October 2021).

\begin{tabular}{|c|c|c|}
\hline CCDR Smart City & Department & $\begin{array}{l}\text { Strategic Projects related to Digital Rights } \\
\text { https://citiesfordigitalrights.org/cities }\end{array}$ \\
\hline $\begin{array}{l}\text { 1. Long Beach } \\
\text { https://citiesfordigitalrights.org/ } \\
\text { city/long-beach }\end{array}$ & Technology and Innovation & 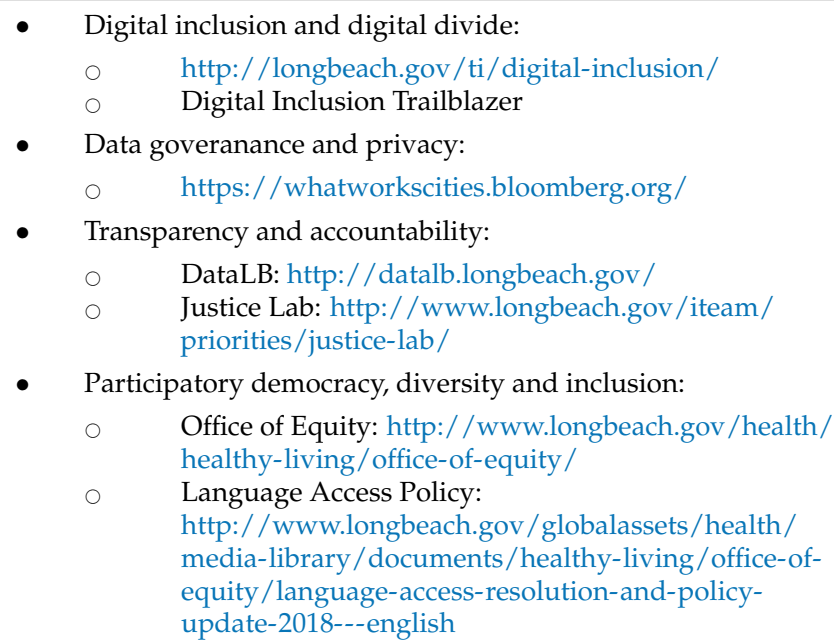 \\
\hline
\end{tabular}

- Improving transit reliability, speed and capacity by trying out new ideas like the King Street Pilot

- $\quad$ Adjusting traffic signals to respond to real-time traffic patterns like the Smart Traffic Signals Pilot

https:/ / citiesfordigitalrights.org/ city/toronto
2. Toronto

Technology Services

- Understanding your water use by day week, month, or year through the MyWater Toronto app

- Making inspection results transparent for more than 15,000 restaurants on the DineSafe map

- Using open data to help solve civic issues on the City's Open Data Initiative

- $\quad$ Establishing a new role of Chief Information and Security Officer (CISO)

- Participatory democracy, diversity, and inclusion:

\section{Porto}

https:/ / citiesfordigitalrights.org /

city/porto
Communications, Networks, and Infrastructures

$\begin{array}{ll} & \text { Porto Innovation Hub } \\ & \text { ScaleUp Porto programme } \\ & \text { Hackacity Porto }\end{array}$

Desafios Porto

\section{Amsterdam}

https:/ / citiesfordigitalrights.org /

city/amsterdam
$\mathrm{CTO} / \mathrm{CIO}$

- DataLab: https://www.amsterdam.nl/bestuur-organisatie/ organisatie/overige/datalab-amsterdam/

- OpenCity: https://www.amsterdam.nl/bestuurorganisatie/meedenken-meepraten/openstad-online/

- Decode: https://decodeproject.eu/

- Smarter London Together Roadmap: https:/ / www.london.gov.uk/sites/default/files/smarter_ london_together_v1.66_-_published.pdf

- London Datastore: https://data.london.gov.uk/

- Crowdfund London: https://www.london.gov.uk/what-we-do/regeneration/ funding-opportunities/crowdfund-london

\section{London}

https:// citiesfordigitalrights.org/ Chief Digital Officer Office city/london
- Mayor's Civic Innovation Challenges: https:/ / www.civicinnovation.london/

- Digital Talent Programme: https://www.london.gov.uk/what-we-do/skills-andemployment/skills-londoners / digital-talent-programme

- $\quad$ Sharing Cities with European Cities: http:/ / www.sharingcities.eu/

- Data Trust with the Open Data Institute: https://theodi.org/ article/uks-first-data-trust-pilots-to-be-led-by-the-odi-inpartnership-with-central-and-local-government/ 
Table 2. Cont.

\begin{tabular}{|c|c|c|}
\hline CCDR Smart City & Department & $\begin{array}{l}\text { Strategic Projects related to Digital Rights } \\
\text { https://citiesfordigitalrights.org/cities }\end{array}$ \\
\hline $\begin{array}{l}\text { 5. London } \\
\text { https://citiesfordigitalrights.org/ } \\
\text { city/london }\end{array}$ & Chief Digital Officer Office & $\begin{array}{l}\text { - Smarter London Together Roadmap: } \\
\text { https://www.london.gov.uk/sites/default/files/smarter_- } \\
\text { london_together_v1.66_-_published.pdf } \\
\text { - } \quad \text { London Datastore: https://data.london.gov.uk/ } \\
\text { - Crowdfund London: } \\
\text { https://www.london.gov.uk/what-we-do/regeneration/ } \\
\text { funding-opportunities/crowdfund-london } \\
\text { Mayor's Civic Innovation Challenges: } \\
\text { https://www.civicinnovation.london/ } \\
\text { Digital Talent Programme: } \\
\text { https://www.london.gov.uk/what-we-do/skills-and- } \\
\text { employment/skills-londoners/digital-talent-programme } \\
\text { - Sharing Cities with European Cities: } \\
\text { http://www.sharingcities.eu/ } \\
\text { Data Trust with the Open Data Institute: https://theodi.org/ } \\
\text { article/uks-first-data-trust-pilots-to-be-led-by-the-odi-in- } \\
\text { partnership-with-central-and-local-government/ }\end{array}$ \\
\hline $\begin{array}{l}\text { 6. Vienna } \\
\text { https://citiesfordigitalrights.org/ } \\
\text { city/vienna }\end{array}$ & CIO Office & $\begin{array}{ll}\text { - } & \text { Digital Humanism: } \\
\text { https://www.ec.tuwien.ac.at/dighum2019 } \\
\text { - } \quad \text { Digital Agenda Wien: http://www.digitaleagenda.wien/ }\end{array}$ \\
\hline $\begin{array}{l}\text { 7. Milan } \\
\text { https://citiesfordigitalrights.org/ } \\
\text { city/milan }\end{array}$ & $\begin{array}{l}\text { Office of the Deputy Mayor for } \\
\text { Digital Transformation and } \\
\text { Services to Citizens }\end{array}$ & $\begin{array}{l}\text { - Digital Folder: http://www.comune.milano.it/wps/portal/ } \\
\text { ist/it/servizi/fascicolocittadino } \\
\text { School-Work Alternation Program: } \\
\text { http://www.comune.milano.it/wps/portal/ist/it/news/ } \\
\text { primopiano/archivio_dal_2012/educazione_istruzione/ } \\
\text { miur_alternanza_scuola_lavoro }\end{array}$ \\
\hline $\begin{array}{l}\text { 8. Barcelona } \\
\text { https://citiesfordigitalrights.org/ } \\
\text { city/barcelona } \\
{[67,107]}\end{array}$ & CIO Office & $\begin{array}{ll}\text { - } & \text { Ethical Digital Standards: } \\
\text { https://www.barcelona.cat/digitalstandards } \\
\text { - } \quad \text { Decidim: https://www.decidim.barcelona/ } \\
\text { Barcelona Open Data portal: } \\
\text { - https://opendata-ajuntament.barcelona.cat/en/ } \\
\text { - } \quad \text { Decode: https://decodeproject.eu/ } \\
\quad \text { Chief Data Officer }\end{array}$ \\
\hline $\begin{array}{l}\text { 9. Los Angeles } \\
\text { https:// citiesfordigitalrights.org/ } \\
\text { city/los-angeles }\end{array}$ & $\begin{array}{l}\text { Mayor's Office of Budget and } \\
\text { Innovation }\end{array}$ & - Information Technology Agency: https://ita.lacity.org/ \\
\hline $\begin{array}{l}\text { 10. Portland } \\
\text { https://citiesfordigitalrights.org/ } \\
\text { city/portland }\end{array}$ & $\begin{array}{l}\text { Smart City PDX-Bureau of } \\
\text { Planning }\end{array}$ & $\begin{array}{l}\text { - Digital Equity Action Plan (DEAP): } \\
\text { https://www.smartcitypdx.com/guiding-principles } \\
\text { - City of Portland Privacy and Information Protection } \\
\text { Principles }\end{array}$ \\
\hline $\begin{array}{l}\text { 11. San Antonio } \\
\text { https:// citiesfordigitalrights.org/ } \\
\text { city/san-antonio }\end{array}$ & Innovation & $\begin{array}{ll}\text { - } & \text { CivTechSA: https://www.civtech-sa.com/ } \\
\text { - } & \text { SmartSA: https://www.sanantonio.gov/smartsa }\end{array}$ \\
\hline $\begin{array}{l}\text { 12. New York City } \\
\text { https://citiesfordigitalrights.org/ } \\
\text { city/new-york-city }\end{array}$ & Mayor's Office of the CTO & $\begin{array}{l}\text { - Cities Open Internet Pledge: } \\
\text { https://actionnetwork.org/letters/sign-to-email-your- } \\
\text { mayor-set-net-neutrality-protections-in-my-city } \\
\text { - } \quad \text { Library Privacy Week: https://libraryprivacyweek.nyc/ }\end{array}$ \\
\hline $\begin{array}{l}\text { 13. Glasgow } \\
\text { https://citiesfordigitalrights.org/ } \\
\text { city/glasgow }\end{array}$ & Chief Executive Department & $\begin{array}{l}\text { - Digital Glasgow Strategy: } \\
\text { https:// www.glasgow.gov.uk//councillorsandcommittees / } \\
\text { viewSelectedDocument.asp?c=P62AFQDN2UUTDNUT81 }\end{array}$ \\
\hline
\end{tabular}

\section{Results and Discussion}

In order to provide further rich insights about the results and findings from this primary research, the responses given by each city representative are contextualised with the description provided in Table 2.

\subsection{Digital Rights' Understanding}

Question 1 (Q1): Digital rights are associated mostly by all European cities with digital inclusion awareness as a direct result of the GDPR, whereas in the case of North American cities, they reflect the value of public consultations in reference to Toronto and the so-called case of Sidewalk Labs [108-110], the explicit concern about selling personal 
data (Los Angeles), the claim for the universal broadband (NYC), and the relationship with broader universal rights and anti-racism (Portland).

For instance, through the open-ended response, Toronto referred to digital rights policies through the open-ended response provided as a way to 'reflect community and stakeholders input (gained through consultation), that actually are understood by residents, supported by decision-makers, and embraced through implementation by the municipality'. Toronto shows an interesting turning point through several strategic projects (e.g., the King Street Pilot, Smart Traffic Signals Pilot, MyWater Toronto app, DineSafe map, and Open Data Initiative) and the newly established role of Chief Information and Security Officer (CISO).

In a similar vein, but by contrast in Europe, Porto indicates that the city administration has appointed 'the Data Protection Officer in the early stage following the GDPR guidelines and enforcing anonymity in the citizen related data insofar as cloud ecosystems are avoided and in-house cloud independent solutions are the current practices preventing external corporate access'. Porto shows a plethora of initiatives related to participatory democracy: the Porto Innovation Hub, ScaleUp Porto Programme, Hackacity Porto, and Desafios Porto (see Table 2).

The understanding of digital rights, in both the US and in Europe, is therefore associated with privacy issues, where data are stored and which stakeholders have the access to that data. Sooner rather than later, data sovereignty will more than likely be included in the CCDR policy agenda given the responses received by city representatives/strategists [85].

Question $2(\mathrm{Q} 2)$ : The understanding of digital rights is very much associated with the following CCDR priority areas: The first option is clearly digital inclusion followed by privacy regulation. The priorities of open technologies and data economy were ranked equally as third and fourth options. The option less ranked by cities was the one related to accountable decision-making in AI. City representatives/strategists thus show a clear concern regarding the algorithmic disruption and the side-effects of lack of privacy in social inclusion. Digital and data divides are clearly two notions that are part of the 'people-centered smart cities' formulation as well $[6,8,47]$.

Given the analysis of the responses received, this article interprets that $\mathrm{AI}$ is seemingly not yet in city administration policy agendas. Only Barcelona and Los Angeles ranked $\mathrm{AI}$ as a priority. However, it seems rather likely that local administrations will start including government measures for municipal algorithms and a data strategy for the ethical promotion of AI, as recently has been the case in Barcelona [111-118].

Question 3 (Q3): All the cities were actively implementing projects, with the exception of a few early members. Table 2 shows a thorough detailed description of the cities' strategic projects related to digital rights. Most of them seems to evolve from the Open Government Data approach towards data protection and digital rights. This research attempted to unpack the multistakeholder composition as a crucial factor to better infer how data ownership and flows were arranged at the city level (See Q10 and Q11).

Question 4 (Q4): Regarding the nature of projects, several cities mentioned 'big community engagement component' through 'community advisory groups' with 'volunteer residents,' whereas others are combining 'start-up ecosystems' with 'municipality citizen cards' and 'emerging technology charters' by highlighting the paradigm of 'digital humanism.' Several cities were actively launching knowledge exchange activities through workshops and festivals bringing together experts and citizens, by and large involving universities and civil society. Nonetheless, some hindrances and barriers were found also for implementing such projects: public trust, financial support, and sponsorship. Institutional innovation sometimes bumps into barriers not only inside of the city administration but also outside it $[22,24,26]$.

Digital commons was an approach mentioned by several city representatives in relation to the way city administrations were opening their internal processes to involve residents in civic technology testing and design. That was the case in Long Beach, although there were other cases taking a gradual approach, such as Toronto: A Community Advisory 
Group consisting of 25 volunteer residents that had interest in the digital infrastructure of the city prepared a broader consultation with the community. Social Innovation can thus effectively blend with technological innovation, resulting in institutional and digital innovation through digital rights (Figure 1).

Alternatively, cities like Porto show another approach: relying on a citizen card as a basic form to nurture digital citizens. Another example is Amsterdam, which has been working with an AI register, creating a local permit for sensors, launching a document on digital rights aimed at citizens, and broadly coordinating with the national government, acting as its flagship testbed. London was developing its 'Emerging Technology Charter', which was outlining what the city administration expected emerging technologists could contribute to the city. Vienna launched a new brand called 'digital humanism' by developing dissemination activities. Milan launched 'Citizen Voices Citizen for Digital Rights', which is a program of workshops with experts and citizens. Barcelona City Council in collaboration with Xnet, has established an 'Ecosystem for Digital Rights' as a repository of 46 initiatives stemming from civil society.

Question 5 (Q5): Ultimately, regarding specific contextual issues, the city of Toronto acknowledges that 'the Sidewalk Labs smart city proposal on Toronto's waterfront certainly put a spotlight on these issues' and added that 'it gained significant media attention, which helped raise awareness of the importance of digital rights amongst residents and decisionmakers.' As such, this testimony by the city representative of Toronto makes an extremely relevant point regarding the failure of the surveillance capitalism in favour of the active claim to the 'right to have digital rights' [108-110]. It is probable that future research on the nexus between digital rights and smart cities might need to provide in-depth ethnographic analysis by including multi-stakeholder framework mapping as a way to provide further insights about the real options around institutional innovation $[95,96]$.

However, institutional innovation probably requires going beyond the institutional barriers. Whereas Porto, by focusing on the internal context of the city administration, identified the local authority's 'workers as a point to start bringing knowledge and a better understanding of digital rights'; Portland shows an entirely different direction by focusing on the external context of the city administration: 'Portland is looking at digital rights from an anti-racism and universal perspective. We are working on a legal framework around the concept of Digital Justice. By using the term "citizenship" in the US, many groups are automatically disenfranchised, particularly immigrants and indigenous communities (Native Americans). We intentionally avoid using citizens and instead we focus on universal rights.'

COVID-19 was another contextual factor that was a relatively common pattern. According to San Antonio's city representative/strategist, the 'pandemic has elevated the importance of digital inclusion for distance learning'. The same representative/strategist later added, 'since the most of our services must be virtual during the pandemic, specific attention is being paid to the digital divide'.

\subsection{Digital Rights' Prioritisation}

Question 6 (Q6): When it comes to prioritising the five digital rights that CCDR focuses on, disparities surfaced among cities. Despite the fact that (i) the universal and equal access to the Internet and digital literacy overall were ranked in the first position; Long Beach and Porto prioritised in second position at a similar level, (ii) open and ethical digital service standards and (iii) privacy, data protection, and security; (iv) participatory democracy, diversity, and inclusion were equally prioritised in second position by cities including Toronto, Vienna, Milan, Barcelona, and NYC. Ultimately, cities put (v) transparency, accountability, and non-discrimination of data, content, and algorithms as the final option. This result shows the clear existing alignment between UN-Habitat's people-centered smart city emerging approach and the CCDR advocacy in terms of the substantial importance about digital divide and literacy. Again, algorithmic transparency very much related to AI seemed to not yet be a priority given that city representatives/strategists were pretty much 
consistent with the response provided in Q2 (in relation to the lowest rank for the option 'Accountable decision-making in $\mathrm{AI}^{\prime}$ ).

Questions 7 and 8 (Q7/Q8): At present, all CCDR cities are embedding the formulation of digital rights in projects, initiatives, and internal dynamics. Table 2 provides a clear indication of the active approaches of the 13 CCDR cities. That shows a strategic intention being part of the CCDR but also equally shows that there are different strategic pathways to activate initiatives at the city level. The strategic implementations of these digital rights rely on the multistakeholder composition in each city $[95,96]$. These projects, initiatives, and internal dynamics are extremely different from city to city and demonstrate that changing the technopolitical awareness through social innovation is not essentially a matter related to altering digital infrastructures. As the literature review on digital rights and smart cities elucidates, a policy experimentation as the joint attempt that the CCDR, as a global citynetwork, is trying to implement will require changes in the way technological innovation relates to data ecosystems in cities [75].

Question 9 (Q9): Regarding the expectations of the cities to achieve strategic implementation of digital rights, Amsterdam, Vienna, San Antonio, and Glasgow had 'high' hopes of reaching completion, whereas the rest showed 'medium' hopes. Not surprisingly, and being entirely realistic, none of the cities expect 'full' or 'low' or even 'no' evolution of their implementations.

Question 10 (Q10): When asking about the most critical stakeholder to achieve more protection for digital rights, the responses given by city representatives/strategists significantly vary, even the context particularising in-depth and acknowledging that local contextual conditions matter [95,96]. We could group the responses as follows: (i) several cities, including Long Beach, Toronto, NYC, London, Los Angeles, and San Antonio, responded 'residents and community-based organizations'; (ii) others, such as Milan and Barcelona clearly indicated 'private tech companies providing public services'; finally, (iii) cities like Porto mentioned 'specific research groups from the academia,' Amsterdam mentioned the 'Waag Society as the key strategic partner,' and Portland and Glasgow cited current 'political leaders.'

Toronto, being again a paradigmatic case due to the so-called case of Sidewalk Labs, indicated that the most critical stakeholders were undoubtedly communities and residents. Given the opened-ended questions asked, the progressive and exploratory action research process provided the following rich insights. The reason given by Toronto's city representative/strategist was because 'successful policy and strategic formulation requires active community engagement and consultation'. The Toronto city representative/strategist added later that 'residents must first understand these complex issues, before they can actively provide their input. Residents must then be able to see their input reflected in the output of this process through policy formulation. If they do not, then the process will fail in two ways: First, it will not reflect the position of the community, and subsequently, is unlikely to be supported by decision-makers'.

However, London provided an interesting response insofar as citizens can be reached if city administrations are necessarily devolved, which means that data devolution [4] should be ensured to deliver digital services to citizens. Thus, even if the most critical stakeholders are citizens, the way to reach these citizens through multi-level governance and data devolution is similarly critical. According to the city representative/strategist of London, 'The most critical stakeholder accessing our citizens are the 33 London boroughs that are within the area administered by Greater London Authority. These 33 boroughs deliver services directly to citizens and collect their data, so they are extremely relevant intermediaries to the protection of digital rights'. This response shows the importance of having a democratic ecosystem to strike a balance between data governance and ownership.

Multi-stakeholder framework compositions vary significantly from city to city by showing distinct strategies regarding the priority given to each stakeholder group [96]. However, this article interprets that common policy patterns arose insofar as all the cities considered a wide multi-stakeholder policy framework beyond the so-called and hege- 
monic private-public-partnership (PPP), which in itself shows a socially innovative institutional and strategic mindset in CCDR cities.

Question 11 (Q11): Hence, as the final question examining multi-stakeholder composition following the Penta Helix framework in each city in terms of which stakeholder group creates or supports the existing ecosystems for digital rights protection, the general ranking shows a clear picture in favour of public institutions, followed by civil society (civil groups, associations, and NGOs) showing an active civilian fabric in all CCDR cities [96]. In second and third positions are ranked these groups, respectively: on the one hand, academia and research centres, and on the other hand, social entrepreneurs, urban activists, and change-makers. Not surprisingly, private companies are less likely to be supportive stakeholder groups in all cities, being in the last position of the given options. Nonetheless, remarkably, there are nuanced distinctions from case to case by showing this trend: Whereas Amsterdam, London, Milan, Portland, and Glasgow favoured public institutions, San Antonio and NYC gave high rankings to academia and research centres. Porto ranked social entrepreneurs, urban activists, and change-makers in the highest position.

The Penta Helix policy framework has been proven to be a dynamic way to map out stakeholders in city ecosystems [96]. The different responses provided by each city representative/strategist may show how the strategic route towards digital rights in each city is clearly reliant on the interplay among stakeholders and their intrinsic power to influence and mobilise resources and agencies.

\section{Conclusions}

COVID-19 has been a trigger for accelerating the side effects of digital transformations on the daily operations of people-centered smart cities and by directly affecting citizens' awareness of their right to claim their digital rights [32].

From an urban perspective, 13 CCDR cities showed that a multistakeholder approach is necessary to deal with datafication processes in smart cities to avoid the hubris of large digital corporations when it comes to engaging with people, cities, and real life. The advocacy of digital rights essentially resonates not only with the need to understand the idiosyncrasies of urban development but also with the nitty-gritty details of the technopolitics of data governance models in each place $[4,119,120]$. Striking cases such as Sidewalk Labs in Toronto have been at the forefront of such technopolitical debates that CCDR are trying to deal with at the global level and in a collaborative manner through its city-network [121]. The longer-term consequences of COVID-19 could also contribute to an erosion of the tech ecosystem that Big Tech corporations usually depend on. As Zukin argues, city administrations pushing ahead institutional innovation demands 'a mayor and a city council united behind a muscular strategy of economic development, environmental adaptation, and business regulation that no one has yet imagined.' [122] (p. 27).

The main contribution of this article is threefold: methodological, empirical, and conceptual, respectively. First, it uses exploratory and progressive action research in collaboration with the CCDR core team to obtain rich and unexplored insights directly by asking 13 CCDR city representatives/strategists. As a result of this, second, preliminary empirical findings revealed not only distinct strategic routes and pathways but also common policy patterns in order to implement digital rights projects and initiatives among CCDR cities. Consequently, third, this article conceptually renovates the technocratic and hegemonic discourse around smart cities by using real cases from 13 global smart cities that belong to the CCDR city-network. As such, this article argues that the understanding and prioritisation of digital rights in these 13 cases will probably lead by clearly influencing other cities and urban areas through a new strategic and policy formulation around smart cities worldwide. These three inputs altogether represent an essential, novel, and original research articulation to contribute to the academic literature in the following knowledge domains and fields: smart cities, digital rights, and action research.

This article, unlike other papers in the past, contributes to the literature by: (i) adding the direct and explicit testimony of city representatives/strategists in their attempt to formu- 
late stringent and timely strategies to cope with digital-rights related issues; (ii) blending digital rights and smart cities through a new version advocated by UN-Habitat called 'people-centered smart cities'; (iii) exploring what digital rights may mean in practical terms for city representatives/strategists; (iv) unpacking strategic formulations related to digital rights; and (v) comparing 13 global cities in a way the findings reveal different strategies through common policy patterns.

This exploratory and progressive action research aimed to gather evidence of how the 13 examined CCDR cities were implementing their city strategies advocating digital rights $[105,106,111,120]$. City governments in these cities have demonstrated an active position in experimenting and pursuing the right to have rights for their fellow citizens by spurring their five strategic digital rights: (i) the right to equal and universal access to the Internet (digital literacy), (ii) the right to privacy, data protection, and security; (iii) the right to transparency, accountability, and non-discrimination in data, content, and algorithms; (iv) the right to participatory democracy, diversity, and inclusion; and (v) the right to open and ethical digital service standards.

To respond to the research question, this article took an exploratory and progressive action research approach to examining how Barcelona, Amsterdam, NYC, Long Beach, Toronto, Porto, London, Vienna, Milan, Los Angeles, Portland, San Antonio, and Glasgow are implementing their digital rights strategies and policies by acknowledging that these cities conceive and deliver these public policies and services to protect their fellow citizens' digital rights. Policy experimentation and institutional innovation though occurs in a distinct manner through a different set of strategies and priorities. Thus, this article concludes that contextual factors and the stakeholders' composition dimension in each city determine by and large the priority given to each digital right. Furthermore, we could argue that there is no one route for advocating digital rights in smart cities from the institutional innovation perspective. However, it has been demonstrated that several alliances among stakeholders may work better than others. The attempt of the new brand people-centered smart cities coined by UN-Habitat is a step forward in this forward-looking view from the social innovation perspective.

The main conclusion of this research is twofold.

First, the semi-structured questionnaire provided a rich diverse set of initiatives and projects in each city, which offer great potential as global influencers of other cities beyond the CCDR network [121]. Additionally, second, despite this broad and remarkable set of diversity in the implementations, this article found common policy patterns among them. Consequently, we can elucidate them as final remarks:

First, the understanding of digital rights was very much related to digital inclusion with a strong community engagement component but equally challenged by the lack of public and financial support. Furthermore, this understanding could be seen as a direct response to the excesses of surveillance capitalism (particularly among the U.S. cities belonging to the CCDR) and as active claims to 'the right to have digital rights' by fellow citizens. This conclusion is remarkable and novel by contrasting with the current literature on comparative research on smart cities insofar as digital rights-related aspects are clearly overlooked [123-129]. Primary research showed the post-GDPR influence in cities such as Porto, Amsterdam, London, Vienna, Milan, Barcelona, and Glasgow. Unlike previous research and publications that focused on benchmarking factors $[130,131]$, this article directly approached city representatives/strategists by asking them to unfold their understanding around digital rights. Insofar as previous research revealed the need for enlarging the ecosystem of e-services in city administration to include citizens, the third sector, entrepreneurs, and activists; this article, by using recent research on Penta Helix model [96], not only included these stakeholders in the semi-structured questionnaire but also explored digital rights through these multistakeholder lenses. This article also elucidated the fact that despite the fact AI is not explicitly considered in city strategies yet, it is a matter of time. Barcelona as the CCDR leading city is paving the way in this direction [111]. 
Consequently, and second, the most prioritised digital right among the cities was the universal and equal access to the Internet and digital literacy, despite the fact that the identification of the most critical stakeholders in a city varied considerably, although 'residents and community-based organizations' were seen in several U.S. cities as a common pattern. Equally, CCDR cities overall depict an active civilian fabric that creates and supports the existing ecosystems for digital rights protection encompassing public institutions and civil groups, associations, and NGOs, both jointly advocating 'the right to have digital rights' as a vehicle for change and experimentation in digital policies from the social innovation perspective $[24-26,31,58,120]$. Primary research showed that there is an increasing concern around the way city administrations need to approach residents. Unlike previous research, this article may open a new manner to consider multistakeholder policy schemes from the digital rights perspective. In the interplay among stakeholders there are opportunities to nurture new data governance models such as data co-operatives. By providing empirical rich insights, the novel contribution of this article is to show how 13 global smart cities by leading a global movement in favour of digital rights from city administrations are more than willing to experiment with new technopolitical routes stemming from data sovereignty, to allow data devolution, to subvert data colonialism, and to foster data justice [85]. Overall, and against the post-COVID-19 backdrop, the rich insights of this article could be summarised with this statement: the advocacy of digital rights in city administrations worldwide may not represent any longer an option but a necessity given the unprecedented nature of the postpandemic algorithmic disruption embodied through surveillance capitalism and social credit systems' stringent human behavioural patterns.

This research, being exploratory by nature, was not meant to provide a full explanation on digital rights, but instead it contributes to opening new future and critical avenues in the techno-political research on comparative smart cities studies in relation to institutional, social, and technological innovations [22-26,121]. It shows that achieving institutional innovation by city administrations will inevitably require an understanding and prioritisation of an increasing set of digital rights as those established and implemented by the CCDR and advocated by UN-Habitat directly through the new brand 'people-centered smart cities' $[6,8]$.

This article also may acknowledge a methodological limitation too. The sample consisting of 13 city representatives/strategists' criteria and responses could be seem as a limitation in itself. However, as clearly indicated throughout this article, the methodology carried out was action research consisting of eight methodological steps as shown in Figure 2. The semi-structured questionnaire provided a comprehensive and comparative standpoint around different strategies being implemented in 13 CCDR cities in November 2020. The validity and representativeness of such methods has been highly demonstrated in the methodological literature in social sciences $[105,106]$. However, this article equally acknowledges that this research should be completed with deeper investigations in the future to prove these conclusions. Thus, the validity of this method remains extremely crucial for further research in the field of digital rights and smart cities.

Regarding future research avenues, in the aftermath of COVID-19 and the algorithmic disruptive era in smart cites, new models of urban governance for city administration should pay further attention to digital rights as one of the key factors for sustainable urban development. It goes without saying that pandemic and algorithmic crises are two sides of the same coin with clear consequences for the sustainability of the urban living and citizens' digital rights. Stemming from and inspired by the CCDR smart city cases, future research could clearly evolve towards how these institutional reactions in city administrations around digital rights are taking place in different locations worldwide.

Against the backdrop of this Special Issue called 'Social Innovation in Sustainable Urban Development', several questions remain unanswered for future research in social, technological, and institutional innovation: (i) What are, in fact, the technopolitical arrangements being made between city administrations and Big Tech corporations [38]? (ii) What do these technopolitical arrangements look like and how does each side understand their 
role in relation to the Penta Helix policy framework [96]? (iii) What power asymmetries and incongruences exist alone therein? and ultimately, (iv) what modes of communication are happening at the urban planning level?

To sum up, the people-centered smart cities approach, as demonstrated by the 13 CCDR cities, will elucidate a strategic pathway in which institutional innovation, exacerbated now in the postpandemic era, will include locally rooted understanding and prioritisation of digital rights. To sum up, this article has paid particular attention to the way digital rights discourse has been already embedded in the institutional digital strategies of 13 CCDR cities. The author hopes that this exploratory action research will invite additional research on social, institutional, and technological innovation studies and spark a debate about the need to include digital rights in the strategic and operational sustainable formulations of smart cities worldwide [132-135].

Funding: The research was funded by the Economic and Social Research Council (ESRC), Grant Number ES/S012435/1 WISERD Civil Society: Changing Perspectives on Civic Stratification and Civil Repair.

Institutional Review Board Statement: Not applicable.

Informed Consent Statement: The 13 CCDR city representatives/strategies were asked for an informed consent when sending the questionnaire. They all approved the informed consent statement provided in the questionnaire.

Data Availability Statement: Not applicable.

Acknowledgments: For the fieldwork research, the support provided by the core team of the CCDR was crucial. Particularly, the author wants to explicitly acknowledge the collaboration with Marc Pérez-Batlle and Joan Batlle-Montserrat, as the key members of the CCDR core team directly involved in the research design, validation of the findings, and project administration. In addition, the author would like to explain that the preliminary stages of this research design were developed by him at the European Commission's Joint Research Centre (JRC), Centre for Advanced Studies (CAS)-Digitranscope and Digital Economy Unit-AI Watch in Italy in close collaboration with Marc Pérez-Batlle and Joan Batlle-Montserrat from the CCDR. At that time (January-November 2020), the author was directly involved as Senior Scientist/scientific officer in two flagships programmes as an attempt to indirectly explore the importance of digital rights in smart cities: DigiTranScope and AI Watch programmes. Sincerely, these acknowledgements therefore are for Marc Pérez-Batlle and Joan Batlle-Montserrat. Fundamentally, the author of this article aimed to present the preliminary findings and comprehensively the specific methodological insights and details behind the rationale of action research as an important part of a broader and ongoing study on digital rights carried out in direct collaboration with the CCDR; and indirectly with UN-Habitat, Katja Schaefer and Pontus Westerberg. It goes without saying that this study is extremely grateful for the responses provided by the 13 city representatives/strategists from the examined CCDR cities (Barcelona, Amsterdam, NYC, Long Beach, Toronto, Porto, London, Vienna, Milan, Los Angeles, Portland, San Antonio, and Glasgow).

Conflicts of Interest: The author declares no conflict of interest.

\section{Appendix A. Semi-Structured Questionnaire to Gather 13 CCDR Smart City Representatives/Strategists' Responses (November 2020)}

1. CHARACTERISATION

Q0. Could you please provide the details to the following questions?

$\begin{array}{ll}\circ & \text { City: } \\ - & \text { Department: }\end{array}$

2. UNDERSTANDING OF DIGITAL RIGHTS IN YOUR CITY:

Q1. Which is the most important priority of your city regarding digital rights? (Max 50 words).

Q2. From 1 to 5, being 1 low and 5 high, how could you rank each of the following five actions among the CCDR priority areas for your city? 

a. Privacy regulation
b. Accountable decision-making in AI
c. Open technologies
d. Digital inclusion
e. Data-Economy

Q3. Is your city actively working on to raise citizens awareness on the need to protect their digital rights?
a. Yes, we already have projects
b. No
c. I do not know

Q4. If yes, how? What actions are being implemented by your public authority to raise awareness on the need for protecting digital rights? If no, are there any particular barriers that you would like to highlight? (Max 50 words)?

Q5. Is there any specific contextual aspect that could leverage the relevance of digital rights in your city? Which one? (Max 50 words).

3. PRIORITY OF DIGITAL RIGHTS IN YOUR CITY:

Q6. From 1 to 5 , being 1 low and 5 high, please rank each of the following five digital rights for your city?
a. Universal and equal access to the internet, and digital literacy
b. Privacy, data protection and security
c. Transparency, accountability, and non-discrimination of data, content and algorithms
d. Participatory democracy, diversity, and inclusion
e. Open and ethical digital service standards

Q7. Are you embedding the formulation of digital rights in ongoing initiatives or projects?
a. Yes
b. No
c. I do not know

Q8. Are you embedding the formulation of digital rights in internal dynamics?
a. Yes
b. No
c. I do not know

Q9. How do you think the strategic implementation of these digital rights will evolve in your city in a year time? (Choose one). We expect to achieve:
a. Full
b. High
c. Medium
d. Low
e. No

Q10. Who is the most critical stakeholder in your city (other than the municipality) to achieve more protection for digital rights and why? (Mention just one please and answer why it is the most critical Max 50 words).

Q11. Could you rank the way stakeholders in your city create or support the existing ecosystem for Digital Rights protection (seeing from the Penta Helix framework) [95]. How would you rank the following stakeholder groups-helixes (being 1 low relevancy and 5 high relevance). 


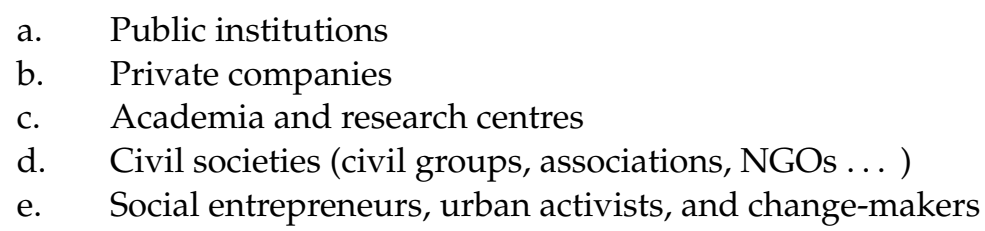

\section{References}

1. Craglia, M.; Scholten, H.; Micheli, M.; Hradec, J.; Calzada, I.; Luitjens, S.; Ponti, M.; Boter, J. Digitranscope: The Governance of Digitally-Transformed Society; EUR 30590 EN; JRC 123362; Publications Office of the European Union: Luxembourg, 2021; ISBN 978-92-76-30229-2. Available online: https://ec.europa.eu/jrc/en/publication/eur-scientific-and-technical-researchreports/digitranscope-governance-digitally-transformed-society (accessed on 8 August 2021). [CrossRef]

2. Gekker, A.; Hind, S. Infrastructural surveillance. New Media Soc. 2019, 22, 1414-1436. [CrossRef]

3. Lightfoot, G.; Wisniewski, T.P. Information asymmetry and power in a surveillance society. Inf. Organ. 2014, 24, 214-235. [CrossRef]

4. Calzada, I. Smart City Citizenship; Elsevier Science Publishing Co Inc.: Cambridge, MA, USA, 2021. [CrossRef]

5. Digital Rights Watch. State of Digital Rights Report. 2021. Available online: https://digitalrightswatch.org.au/2021/02/05/thestate-of-digital-rights-report-a-2020-retrospective/ (accessed on 8 August 2021).

6. Calzada, I. People-Centered Smart Cities; UN-Habitat: New York, NY, USA, 2021; Forthcoming.

7. UN-Habitat. Digital Cities Toolkit: Policy Toolkit for People-Centred Smart Cities. Available online: https://unhabitat.org/ digitalcitiestoolkit/\# (accessed on 8 August 2021).

8. UN-Habitat. People-Centered Smart Cities; UN-Habitat: New York, NY, USA, 2018.

9. United Nations. Extreme Poverty and Human Rights; UN: Washington, DC, USA, 2019.

10. Bigo, D.; Isin, E.; Ruppert, E. Data Politics; Routledge: London, UK, 2019.

11. The British Academy. The COVID Decade: Understanding the Long-Term Societal Impacts of COVID-19; The British Academy: London, UK, 2021.

12. Csernatoni, R. New states of emergency: Normalizing techno-surveillance in the time of COVID-19. Glob. Aff. 2020, 6, 301. [CrossRef]

13. Haug, N. Deducing which pandemic policies work best. Nat. Hum. Behav. 2020, 4, 1303-1312. [CrossRef]

14. Lupton, D.; Michael, M. Depends on who's got the data: Public understandings of personal digital dataveillance. Surveill. Soc. 2017, 15, 254-268. [CrossRef]

15. Maxmen, A. Surveillance Science. Nature 2019, 569, 614-617. [CrossRef] [PubMed]

16. Ada Lovelace Institute. What Place Should COVID-19 Vaccines Passports Have in Society? Ada Lovelace Institute: London, UK, 2021.

17. CDEI (Centre for Data Ethics and Innovation). COVID-19 Repository \& Public Attitudes; CDEI: London, UK, 2021.

18. Kitchin, R. Civil liberties or public health, or civil liberties and public health? Using surveillance technologies to tackle the spread of COVID-19. Space Polity 2020, 24, 362-381. [CrossRef]

19. Digital Rights Archive. Available online: www.digitalrightsarchive.net (accessed on 8 August 2021).

20. CCDR (Cities' Coalition for Digital Rights). City Examples of Digital Rights in Times of COVID-19. Available online: https:/ / citiesfordigitalrights.org/city-examples-digital-rights-times-covid-19 (accessed on 8 August 2021).

21. CDR (Centre for Digital Rights). Available online: www.centrefordigitalrights.org (accessed on 8 August 2021).

22. Angelidou, M.; Psaltoglou, A. An empirical investigation of social innovation initiatives for sustainable urban development. Sustain. Cities Soc. 2017, 33, 113-125. [CrossRef]

23. BEPA Bureau of European Policy Advisers. Empowering People, Driving Change: Social Innovation in the European Union; Publications Office of the European Union: Luxembourg, 2010.

24. Edwards-Schachter, M.; Wallace, M.L. 'Shaken, but not stirred': Sixty years of defining social innovation. Technol. Forecast. Soc. Chang. 2017, 119, 64-79. [CrossRef]

25. Manzini, E. Making things happen: Social innovation and design. Des. Issues 2014, 30, 57-66. [CrossRef]

26. Mieg, H.A.; Töpfer, K. (Eds.) Institutional and Social Innovation for Sustainable Urban Development; Earthscan: London, UK, 2013.

27. Seubert, S.; Becker, C. The democratic impact of strengthening European fundamental rights in the digital age: The example of privacy protection. Ger. Law J. 2021, 22, 31-44. [CrossRef]

28. Willis, K.S.; Aurigi, A. The Routledge Companion to Smart Cities; Routledge: London, UK, 2020.

29. Albino, V.; Berardi, U.; Dangelico, R.M. Smart cities: Definitions, dimensions, performance, and initiatives. J. Urban Technol. 2015, 22, 3-21. [CrossRef]

30. Kitchin, R. Afterword: Decentering the smart city. In Equality in the City: Imaginaries of the Smart Future; Flynn, S., Ed.; Intellect: Bristol, UK, 2021.

31. United Nations. Hub for Human Rights and Digital Technology. Available online: https:/ / www.digitalhub.ohchr.org/ (accessed on 8 August 2021).

32. Arendt, H. The rights of man: What are they? Mod. Rev. 1949, 3, 4-37.

33. Bernstein, R.J. Why Read Hannah Arendt Now? Polity Press: Cambridge, UK, 2018. 
34. Debarbieux, B. Hannah Arendt's spatial thinking: An introduction. Territ. Politics Gov. 2017, 5, 351-367. [CrossRef]

35. DeGooyer, S.; Hunt, A.; Maxwell, L.; Moyn, S. The Right to Have Rights; Verso: London, UK, 2018.

36. Desforges, L.; Jones, R.; Woods, M. New geographies of citizenship. Citizsh. Stud. 2005, 9, 439-451. [CrossRef]

37. Nyers, P. The accidental citizen: Acts of sovereignty and (un)making citizenship. Econ. Soc. 2006, 35, 22-41. [CrossRef]

38. Calzada, I. Technological sovereignty: Protecting citizens' digital rights in the AI-driven and post-GDPR algorithmic and city-regional European realm. Reg. Ezine 2019, 4. [CrossRef]

39. Hintz, A.; Dencik, L.; Wahl-Jorgensen, K. Digital citizenship and surveillance society. Int. J. Commun. 2017, 11, 731-739.

40. Hummel, P.; Braun, M.; Tretter, M.; Dabrock, P. Data sovereignty: A review. Big Data Soc. 2021, 8, 8. [CrossRef]

41. Karppinen, K.; Puukko, O. Four discourses of digital rights: Promises and problems of rights-based politics. J. Inf. Policy 2020, 10, 304-328. [CrossRef]

42. Kitchin, R. Data Lives: How Data Are Made and Shape Our World; Policy Press: London, UK, 2020.

43. Smuha, N.A. Beyond a human rights-based approach to AI governance: Promise, pitfalls, plea. Philos. Technol. 2020, 1-4. [CrossRef]

44. Taylor, L. What is data justice? The case for connecting digital rights and freedoms globally. Big Data Soc. 2017, 4, 2053951717736335. [CrossRef]

45. Ada Lovelace Institute. The Citizens' Biometrics Council: Recommendations and Findings of a Public Deliberation on Biometrics Technology, Policy, and Governance; Ada Lovelace Institute: London, UK, 2021.

46. Ada Lovelace Institute. Checkpoints for Vaccine Passports: Requirements for Governments and Developers; Ada Lovelace Institute: London, UK, 2020.

47. Ada Lovelace Institute. Data Divide: Public Attitudes to Tacking Social and Health Inequalities in the COVID-19 Pandemic and Beyond; Ada Lovelace Institute: London, UK, 2021.

48. Burki, T. Equitable distribution of COVID-19 vaccines. Lancet Infect. Dis. 2021, 21, 33-34. [CrossRef]

49. Katz, I.T.; Weintraub, R.; Bekker, L.-G.; Brandt, A.-M. From vaccine nationalism to vaccine equity-Finding a path forward. N. Engl. J. Med. 2021, 384, 1281-1283. [CrossRef] [PubMed]

50. Barbera, F; Jones, I.R. The Foundational Economy and Citizenship: Comparative Perspectives on Civil Repair; Bristol University Press: Bristol, UK, 2020.

51. Forestal, J. Constructing digital democracies: Facebook, Arendt, and the politics of design. Political Stud. 2020, 69, 26-44. [CrossRef]

52. Goggin, G.; Vromen, A.; Weatherall, K.; Fiona, M.; Lucy, S. Data and digital rights: Recent Australian developments. Internet Policy Rev. 2019, 8, 1-19. [CrossRef]

53. Nguyen, J. Identity, rights and surveillance in an era of transforming citizenship. Citizsh. Stud. 2018, 22, 86-93. [CrossRef]

54. Barlow, J.P. A Declaration of the Independence of Cyberspace. Available online: http://www.eff.org/cyberspace-independence (accessed on 8 August 2021).

55. Amnesty International \& Access Now. The Toronto Declaration. Available online: https://www.torontodeclaration.org (accessed on 8 August 2021).

56. CFDREU (Charter of Fundamental Digital Rights of the European Union). Available online: https://digitalcharta.eu/wpcounten/uploads/DigitalCharter-English-2019-Final.pdf (accessed on 8 August 2021).

57. MFTSDRC (Manifesto in Favour of Technological Sovereignty and Digital Rights for Cities). Available online: https://www. barcelona.cat/digitalstandards/manifesto/0.2/ (accessed on 8 August 2021).

58. Breuer, J.; Pierson, J. The right to the city and data protection for developing citizen-centric digital cities. Inf. Commun. Soc. 2021, 24, 797-812. [CrossRef]

59. Hintz, A.; Dencik, J.; Wahl-Jorgensen, K. Digital Citizenship in a Datafied Society; Polity Press: Cambridge, UK, 2019.

60. Cheney-Lippold, J. A new algorithmic identity: Soft biopolitics and the modulation of control. Theory Cult. Soc. 2011, 28, 164-181. [CrossRef]

61. Zuboff, S. The Age of Surveillance Capitalism: The Fight for a Human Future at the New Frontier of Power; Profile: London, UK, 2019.

62. Ahmed, S. Personal risk and algorithmic opacity: An investigation of user-identified concerns in the construction of the social credit system. In Proceedings of the Working Paper Presented at Freie Universität Berlin, Workshop on Digital Transformation in China-Recent Trends and Impacts, Berlin, Germany, 19 January 2018.

63. Aho, B.; Duffield, R. Beyond surveillance capitalism: Privacy, regulation and big data in Europe and China. Econ. Soc. 2020, 49, 187-212. [CrossRef]

64. Kostka, G. China's social credit systems and public opinion: Explaining high levels of approval. New Media Soc. 2019, 21, 1565-1593. [CrossRef]

65. Calzada, I. Deciphering smart city citizenship: The techno-politics of data and urban co-operative platforms. Rev. Int. De Estud. Vascos RIEV 2018, 63, 42-81. [CrossRef]

66. Gawer, A.; Srnicek, N. Online Platforms: Economic and Societal Effects; EPRS European Parliamentary Research Service: Brussels, Belgium, 2021.

67. Calzada, I. (Smart) citizens from data providers to decision-makers? The case study of Barcelona. Sustainability 2018, 10, 3252. [CrossRef] 
68. Brunswicker, S.; Priego, L.P.; Almirall, E. Transparency in policy making: A complexity view. Gov. Inf. Q. 2019, 36, 571-591. [CrossRef]

69. Digital Future Society. Governing Algorithms: Perils and Powers of AI in the Public Sector; Digital Future Society: Barcelona, Spain, 2021.

70. Wong, P.-H. Democratizing algorithmic fairness. Philos. Technol. 2019, 33, 225-244. [CrossRef]

71. Vesnic-Alujevic, L.; Stoermer, E.; Rudkin, J.; Scapolo, F.; Kimbell, L. The Future of Government 2030+: A Citizen-Centric Perspective on New Government Models; Publications Office of the European Union: Luxembourg, 2019.

72. Lodato, T.; French, E.; Clark, J. Open government data in the smart city: Interoperability, urban knowledge, and linking legacy systems. J. Urban Aff. 2021, 43, 586-600. [CrossRef]

73. Hand, D.J. Dark Data; Princeton University Press: Princeton, NJ, USA, 2020.

74. CCDR (Cities' Coalition for Digital Rights). Declaration of Cities' Coalition for Digital Rights. Available online: https: / / citiesfordigitalrights.org/ (accessed on 8 August 2021).

75. Calzada, I.; Almirall, E. Data ecosystems for protecting European citizens' digital rights. Transform. Gov. People Process Policy 2020 14, 133-147. [CrossRef]

76. CCDR (Cities' Coalition for Digital Rights). Strategy 2020: Action Plan and Roadmap; Barcelona City Council: Barcelona, Spain, 2019.

77. Desouza, K.C.; Kapucu, N.; Wu, J. Special Issue: Smart governance in the contemporary era. J. Urban Aff. 2021, 43, 503. [CrossRef]

78. $\mathrm{Hu}, \mathrm{Q} . ;$ [CrossRef]

79. Löfgren, K.; Webster, C.-W.-R. The value of Big Data in government: The case of 'smart cities'. Big Data Soc. 2020, 7, 1-14. [CrossRef]

80. Seubert, S.; Helm, P. Normative paradoxes of privacy. Surveill. Soc. 2020, 18, 185-198. Available online: https://ojs.library. queensu.ca/index.php/surveillance-and-society/article/view/13356/9300 (accessed on 11 October 2021).

81. Pangrazio, L.; Sefton-Green, J. Digital rights, digital citizenship and digital literacy: What's the difference? J. New Approaches Educ. Res. 2021, 10, 15-27. [CrossRef]

82. Calzada, I.; Cobo, C. Unplugging: Deconstructing the smart city. J. Urban Technol. 2015, 22, 23-43. [CrossRef]

83. Hollands, R.G. Will the real smart city please stand up? City 2008, 12, 303-320. [CrossRef]

84. Costales, E. Identifying sources of innovation: Building a conceptual framework of the Smart City through a social innovation perspective. Cities 2021, 103459, in press. [CrossRef]

85. Calzada, I. Data co-operatives through data sovereignty. Smart Cities 2021, 4, 1158-1172. [CrossRef]

86. IRPC (Internet Rights \& Principles Coalition). The Charter of Human Rights and Principles for the Internet (United Nations Internet Governance Forum, IGF). Available online: https: / / www.google.com/url?sa=t\&rct=j\&q=\&esrc=s\&source=web\&cd= \&cad=rja\&uact=8\&ved=2ahUKEwj06ZfHpsrzAhUHAcAKHcp1CzsQFnoECAIQAQ\&url=https $\% 3 \mathrm{~A} \% 2 \mathrm{~F} \% 2 \mathrm{Fwww}$. ohchr.org $\%$ 2FDocuments\%2FIssues\%2FOpinion\%2FCommunications\%2FInternetPrinciplesAndRightsCoalition.pdf\&usg=AOvVaw0I7 jqOXkjxCO46_6ydTxc2 (accessed on 8 August 2021).

87. Pentland, A.; Hardjono, T. Data Cooperatives: Building the New Economy; MIT: Cambridge, MA, USA, 2020.

88. Isin, E.; Ruppert, E. Being Digital Citizens; Rowman \& Littlefield: New York, NY, USA, 2015.

89. EFF (Electronic Frontier Foundation) Atlas of Surveillance. Available online: https:/ / atlasofsurveillance.org/atlas (accessed on 8 August 2021).

90. RDR (Ranking Digital Rights). Ranking Digital Rights. Available online: https:/ / rankingdigitalrights.org/ (accessed on 8 August 2021).

91. Floridi, L. The fight for digital sovereignty: What it is, and why it matters, especially for the EU. Philos. Technol. 2020, 33, 369-378. [CrossRef]

92. Postigo, H. Digital Rights Movement; MIT Press: Cambridge, MA, USA, 2012.

93. Mathiesen, K. Human rights for the digital age. J. Mass Media Ethics 2014, 29, 2-18. [CrossRef]

94. Daskal, E. Let's be careful out there ... : How digital rights advocates educate citizens in the digital age. Inf. Commun. Soc. 2018, 21, 241-256. [CrossRef]

95. Kummitha, R.K.R.; Crutzen, N. Smart cities and the citizen-driven internet of things: A qualitative inquiry into an emerging smart city. Technol. Forecast. Soc. Chang. 2019, 140, 44-53. [CrossRef]

96. Calzada, I. Democratising smart cities? Penta-helix multistakeholder social innovation framework. Smart Cities 2020, 3, 1145-1172. [CrossRef]

97. Moulaert, F.; MacCallum, D. Advanced Introduction to Social Innovation; Edward Elgar: Cheltenham, UK, 2019.

98. Reason, P.; Bradbury, H. Inquiry and Participation in Search of a World Worthy of Human Aspiration. In Handbook of Action Research: Participative Inquiry and Practice; Reason, P., Bradbury, H., Eds.; Sage Publications: London, UK, 2001.

99. Tolman, D.L.; Brydon-Miller, M. From Subjects to Subjectivities: A Handbook of Interpretive and Participatory Methods; New York University Press: New York, NY, USA, 2000.

100. Elstub, S.; Thompson, R.; Escobar, O.; Hollinghurst, J.; Grimes, D.; Aitken, M.; Mckeon, A.; Jones, K.H.; Waud, A.; Sethi, N. The resilience of pandemic digital deliberation: An analysis of online synchronous forums. Javn.-Public 2021, 1-20. [CrossRef] 
101. Braun, V.; Clarke, V.; Gray, D. Collecting Qualitative Data: A Practical Guide to Textual, Media and Virtual Techniques; Cambridge University Press: Cambridge, MA, USA, 2017.

102. Archibald, M.M.; Ambagtsheer, R.C.; Casey, M.G.; Lawless, M. Using zoom videoconferencing for qualitative data collection: Perceptions and experiences of researchers and participants. Int. J. Qual. Methods 2019, 18, 1-8. [CrossRef]

103. Gauthier, N.H.; Husain, M.I. Dynamic security analysis of Zoom, Google Meet and Microsoft Teams. In Silicon Valley Cybersecurity Conference; Park, Y., Jadav, D., Austin, T., Eds.; Springer International Publishing: Cham, Switzerland, 2021; pp. 3-24.

104. Hewson, C.; Laurent, D. Research design and tools for Internet research. In The Handbook of Online Research Methods; Fielding, N.G., Lee, R., Blank, G., Eds.; Sage Publications: London, UK, 2008.

105. Soeiro, D. Smart cities and innovative governance systems: A reflection on urban living labs and action research. Fennia 2021, 199, 104-112.

106. Bennett, H.; Brunner, R. Nurturing the buffer zone: Conducting collaborative action research in contemporary contexts. Qual. Res. 2020. [CrossRef]

107. Blanco, I.; Salazar, Y.; Bianchi, I. Urban governance and political change under a radical left government: The case of Barcelona. J. Urban Aff. 2019, 42, 18-38. [CrossRef]

108. Baeten, G. Sidewalk Labs' plans for Toronto shake the foundations of planning as we know it. In Plan Canada Fall; Canadian Institute of Planners: Ottawa, ON, Canada, 2020.

109. Sidewalk Labs. Digital Governance Proposals for DSAP Consultation; Sidewalk Labs: New York, NY, USA, 2018.

110. Artyushina, A. Is civic data governance the key to democratic smart cities? The role of the urban data trust in Sidewalk Toronto. Telemat. Inform. 2020, 55, 101456. [CrossRef]

111. Barcelona City Council. Government Measure for a Municipal Algorithms and Data Strategy for an Ethical Promotion of Artificial Intelligence; Barcelona City Council: Barcelona, Spain, 2021.

112. UK Government. A Guide to Using Artificial Intelligence in the Public Sector; Government Digital Service, Office for Artificial Intelligence: London, UK, 2021.

113. UK Government. Data: A New Direction; Government Digital Service, Office for Artificial Intelligence: London, UK, 2021.

114. UK Government. National AI Strategy; Government Digital Service, Office for Artificial Intelligence: London, UK, 2021.

115. Government of Ireland. AI: Here for Good. A National Artificial Intelligence Strategy for Ireland; Government of Ireland: Dublin, Ireland, 2021.

116. Scottish Government. A Changing Nation: How Scotland Will Thrive in a Digital World; Scottish Government: Edinburgh, Scotland, 2021.

117. Welsh Government. Digital Strategy for Wales: How We Will Use Digital, Data and Technology to Improve the Lives of People in Wales; Welsh Government: Cardiff, South Glamorgan, 2021.

118. OECD. Artificial Intelligence in Society; OECD: Paris, France, 2019.

119. Carr, C.; Hesse, M. Sidewal Labs Closed Down-Whither Google's Smart City? Available online: https:/ / regions.regionalstudies. org/ezine/article/sidewalk-labs-closed-down-whither-googles-smart-city/?doi=10.1080/13673882.2020.00001070 (accessed on 8 October 2021).

120. EFF (Electronic Frontier Foundation). EFF's Guide to Digital Rights during the Pandemic; EFF: London, UK, 2021.

121. Acuto, M.; Pejic, D. Shaping a global comparative imagination? Asessing the role of city rankings in the 'global city' discourse. Area 2021, 53, 247-256. [CrossRef]

122. Zukin, S. Planetary Silicon Valley: Deconstructing New York's Innovation Complex. Urban Stud. 2020, 58, 3-35. [CrossRef]

123. Desdemoustier, J.; Crutzen, N.; Giffinger, R. Municipalities' understanding of the smart city concept: An exploratory analysis in Belgium. Technol. Forecast. Soc. Chang. 2019, 142, 129-141. [CrossRef]

124. Hatuka, T.; Zur, H. From smart cities to smart social urbanism: A framework for shaping the socio-technological ecosystems in cities. Telemat. Inform. 2020, 55, 101430. [CrossRef]

125. Lam, P.T.I.; Ruiqu, M. Potential pitfalls in the development of smart cities and mitigation measures: An exploratory study. Cities 2019, 91, 146-156. [CrossRef]

126. Minnar, I.; Avani, S.; Ferrari, V. The Impact of COVID-19 on Digital Rights in Africa; African Declaration on Internet Rights and Freedoms, ADIRF: Johannesburg, South Africa, 2020.

127. Razmjoo, A.; Ostergaard, P.A.; Mouloud, D.; Nezhad, M.M.; Mirjalili, S. Effective policies to overcome barriers in the development of smart cities. Energy Res. Soc. Sci. 2021, 79, 102175. [CrossRef]

128. Ruohonen, J. The treachery of images in the digital sovereignty debate. Mind Mach. 2021, 31, 439-456. [CrossRef]

129. Ylipulli, J.; Luusua, A. Smart cities with a Nordic twist? Public sector digitalisation in Finnish data-rich cities. Telemat. Inform. 2020, 55, 101457. [CrossRef]

130. Rodriguez Bermudez, J.R.; Batlle-Montserrat, J.; Esteban Ayerbe, D. Estudio Europeo sobre e-gobierno en las ciudades. Rev. De Internet Derecho Y Politica. 2007, 5, 1-8.

131. Batlle-Montserrat, J.; Blat, J.; Abadal, E. Local e-government Benchlearning; Impact analysis and applicability to smart cities benchmarking. Inf. Polity 2016, 21, 43-59. [CrossRef]

132. Mehmood, A.; Muhammad, I. Digital social innovation and civic participation: Toward responsible and inclusive transport planning. Eur. Plan. Stud. 2021, 29, 1870-1885. [CrossRef] 
133. Moulaert, F.; Mehmood, A. Towards a social innovation (SI) based epistemology in local development analysis: Lessons from twenty of EU research. Eur. Plan. Stud. 2020, 28, 434-453. [CrossRef]

134. Pel, B.; Wittmayer, J.; Dorland, J.; Sogaard Jorgensen, M. Unpacking the social innovation ecosystem: An empirically grounded typology of empowering network constellations. Innov. Eur. J. Soc. Sci. Res. 2020, 33, 311-336. [CrossRef]

135. Bartels, K. Transforming the relational dynamics of urban governance: How social innovation research can create a trajectory for learning and change. Urban Stud. 2020, 57, 2868-2884. [CrossRef] 